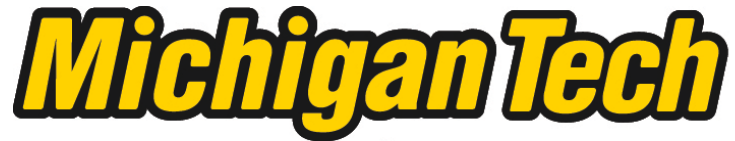 \\ Michigan Technological University Create the Future Digital Commons @ Michigan Tech
}

Dissertations, Master's Theses and Master's Reports - Open

Dissertations, Master's Theses and Master's

Reports

2011

Tropospheric ozone and $\mathrm{CO}$ over North Atlantic for the past decade

Mark F. Weise

Michigan Technological University

Follow this and additional works at: https://digitalcommons.mtu.edu/etds

Part of the Civil and Environmental Engineering Commons

Copyright 2011 Mark F. Weise

\section{Recommended Citation}

Weise, Mark F., "Tropospheric ozone and CO over North Atlantic for the past decade", Master's report, Michigan Technological University, 2011.

https://doi.org/10.37099/mtu.dc.etds/521

Follow this and additional works at: https://digitalcommons.mtu.edu/etds

3 Part of the Civil and Environmental Engineering Commons 


\title{
Tropospheric Ozone and CO over North Atlantic for the Past Decade
}

\author{
By \\ Mark F. Weise \\ A REPORT \\ Submitted in partial fulfillment of the requirements for \\ the degree of \\ MASTER OF SCIENCE
}

Environmental Engineering

\section{MICHIGAN TECHNOLOGICAL UNIVERSITY \\ 2011}


This report, "Tropospheric Ozone and CO over North Atlantic for the Past Decade," is hereby approved in partial fulfillment of the requirements for the Degree of MASTER OF SCIENCE IN Environmental Engineering.

Department of Civil and Environmental Engineering

Signatures:

Report Advisor

Dr. Shiliang Wu

Committee Member

Dr. Robert Chris Owen

Committee Member

Dr. Louisa Kramer

Department Chair

Dr. William M. Bulleit, P.E

Date 


\section{Table of Contents}

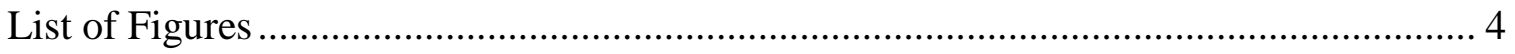

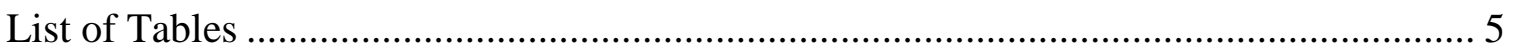

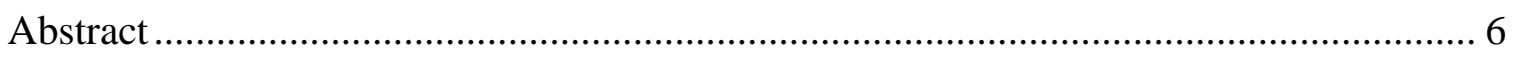

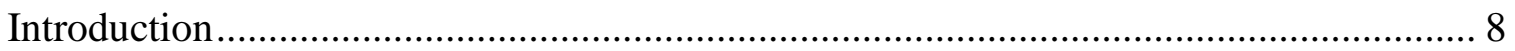

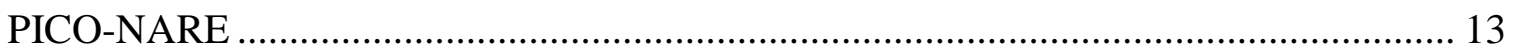

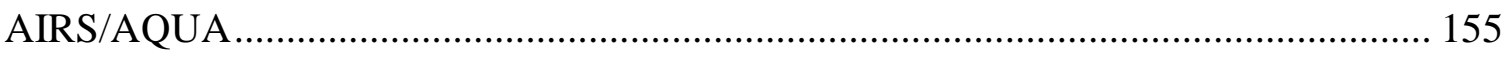

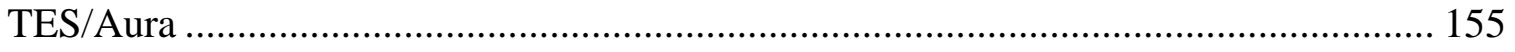

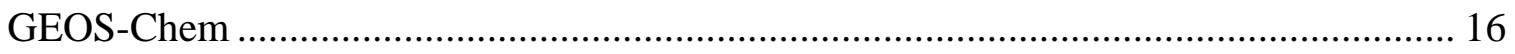

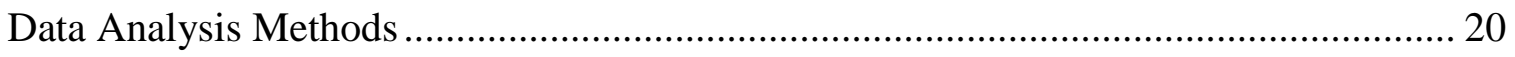

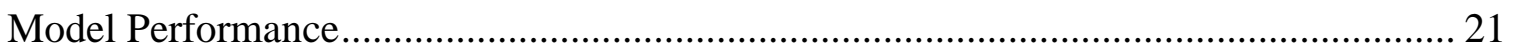

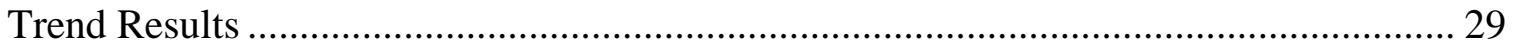

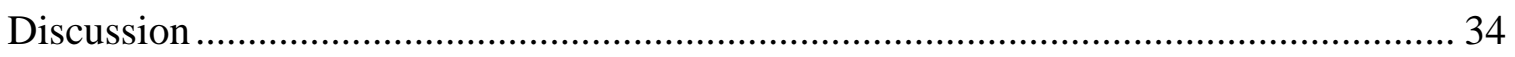

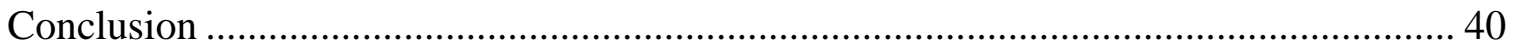

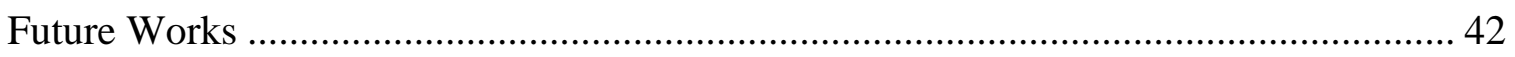

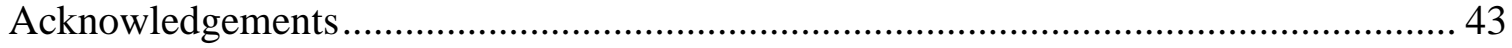

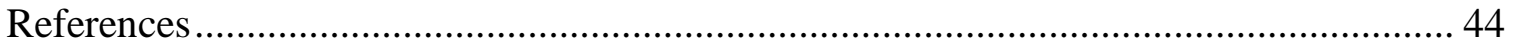

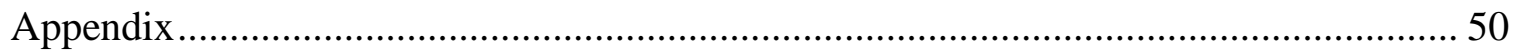




\section{List of Figures}

Figure 1: US Emission Trends.................................................... 10

Figure 2: Horizontal Grid Resolution................................................. 22

Figure 3: $\mathrm{CO}$ w/various Biomass Burning Options...................................... 23

Figure 4: Full Record Timeseries Plot.................................................. 24

Figure 5: GEOS-Chem vs. Pico Data.................................................. 25

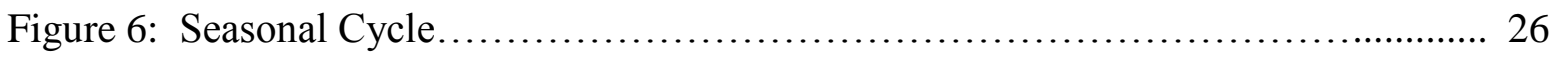

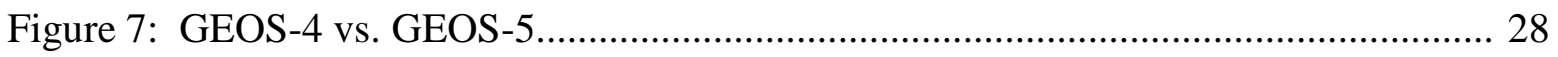

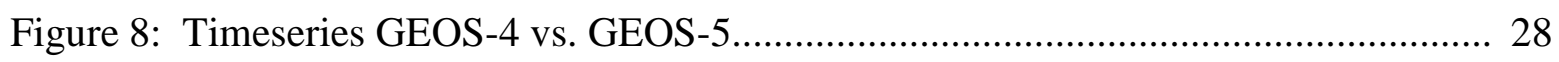

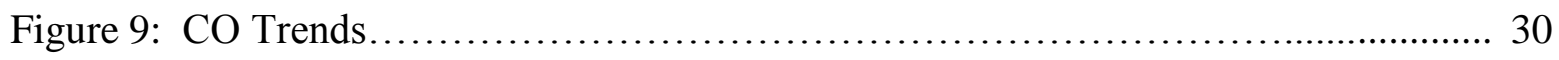

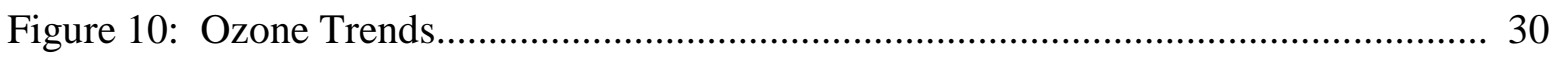

Figure 11: CO Trends No North America Emissions........................................................ 33

Figure 12: Ozone Trends No North America Emissions.................................................. 34

Figure A1: Summer GEOS-Chem vs. Pico Data................................................................. 51

Figure A2: Fall GEOS-Chem vs. Pico Data............................................................... 51

Figure A3: Winter GEOS-Chem vs. Pico Data................................................................... 51

Figure A4: Spring GEOS-Chem vs. Pico Data................................................................... 52 


\section{List of Tables}

Table 1: CO Sources and Sinks........................................................................... 09

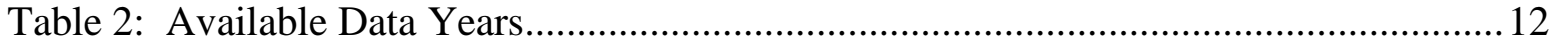

Table 3: GEOS-Chem CO Sources............................................................................... 19

Table 4: Minimum and Maximum Values................................................................26

Table 5: Annual Mean Hydroxyl Radical Concentration................................................... 27

Table 6: Model Trend Results with North American Emisisons....................................... 31

Table 7: North American Contribution to Pico......................................................................32

Table 8: Model Trend Results no North American Fossil Fuel Emissions......................... 34

Table 9: Monthly Average Differences Carbon Monoxide............................................... 35

Table 10: Seasonal and Full Record Average Differences Carbon Monoxide.....................36

Table 11: Monthly Average Differences Ozone........................................................... 37

Table 12: Seasonal and Full Record Average Differences Ozone....................................37

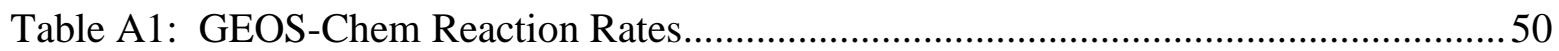

Table A2: Global GEOS-Chem CO Sources.............................................................50

Table A3: US EPA CO Emissions........................................................................52 


\section{Abstract}

We investigate how declines in US emissions of $\mathrm{CO}$ and $\mathrm{O}_{3}$ precursors have impacted the lower free troposphere over the North Atlantic. We use seasonal observations for $\mathrm{O}_{3}$ and $\mathrm{CO}$ from the PICO-NARE project for the period covering 2001 to 2010. Observations are used to verify model output generated by the GEOS-Chem 3-D global chemical transport model. Additional satellite data for CO from AIRS/Aqua and for $\mathrm{O}_{3}$ from TES/Aura were also used to provide additional comparisons; particularly for fall, winter, and spring when PICO-NARE coverage is sparse. We find GEOS-Chem captures the seasonal cycle for $\mathrm{CO}$ and $\mathrm{O}_{3}$ well compared to PICO-NARE data. For CO, GEOS-Chem is biased low, particularly in spring which is in agreement with findings from previous studies. GEOS-Chem is $24.7+/-5.2$ ppbv $(1-\sigma)$ low compared to PICONARE summer CO data while AIRS is $14.2+/-6.6$ ppbv high. AIRS does not show nearly as much variation as seen with GEOS-Chem or the Pico data, and goes from being lower than PICO-NARE data in winter and spring, to higher in summer and fall. Both TES and GEOS-Chem match the seasonal ozone cycle well for all seasons when compared with observations. Model results for $\mathrm{O}_{3}$ show GEOS-Chem is $6.67+/-2.63$ ppbv high compared to PICO-NARE summer measurements and TES was 3.91 +/- 4.2 ppbv higher. Pico data, model results, and AIRS all show declines in $\mathrm{CO}$ and $\mathrm{O}_{3}$ for the summer period from 2001 to 2010. Limited availability of TES data prevents us from using it in trend analysis. For summer CO Pico, GEOS-Chem, and AIRS results show declines of $1.32,0.368$, and 0.548 ppbv/year respectively. For summer $\mathrm{O}_{3}$, Pico and GEOS-Chem show declines of -0.726 and $-0.583 \mathrm{ppbv/year} \mathrm{respectively.} \mathrm{In} \mathrm{other}$ 
seasons, both model and AIRS show declining CO, particularly in the fall. GEOS-Chem results show a fall decline of 0.798 ppbv/year and AIRS shows a decline of 0.8372 ppbv/year. Winter and spring CO declines are 0.393 and 0.307 for GEOS-Chem, and 0.455 and 0.566 for AIRS. GEOS-Chem shows declining $\mathrm{O}_{3}$ in other seasons as well; with fall being the season of greatest decrease and winter being the least. Model results for fall, winter, and spring are $0.856,0.117$, and $0.570 \mathrm{ppbv} / \mathrm{year}$ respectively. Given the availability of data we are most confident in summer results and thus find that summer $\mathrm{CO}$ and $\mathrm{O}_{3}$ have declined in lower free troposphere of the North Atlantic region of the Azores. Sensitivity studies for $\mathrm{CO}$ and $\mathrm{O}_{3}$ at Pico were conducted by turning off North American fossil fuel emissions in GEOS-Chem. Model results show that North America fossil fuel emissions contribute $8.57 \mathrm{ppbv} \mathrm{CO}$ and $4.03 \mathrm{ppbv} \mathrm{O}_{3}$ to Pico. The magnitude of modeled trends declines in all seasons without North American fossil fuel emissions except for summer $\mathrm{CO}$. The increase in summer $\mathrm{CO}$ declines may be due to a decline of $5.24 \mathrm{ppbv} / \mathrm{year}$ trend in biomass burning emissions over the study period; this is higher than the $2.33 \mathrm{ppbv} / \mathrm{year}$ North American anthropogenic $\mathrm{CO}$ model decline. Winter $\mathrm{O}_{3}$ is the only season which goes from showing a negative trend to a positive trend. 


\section{(1) Introduction}

Tracking trends in $\mathrm{O}_{3}$ and $\mathrm{CO}$ is important for both policy makers and scientists. Ozone is the third most important greenhouse gas (GHG), a respiratory irritant, and responsible for $\sim \$ 500$ million dollars per year in crop damage in the US alone [EPA, 2011; $R$ Honrath et al., 2004]. Ozone is also the primary source of the hydroxyl radical $(\mathrm{OH})$, which is the primary oxidant in the atmosphere, and thus impacts the oxidizing ('cleansing') capacity of the atmosphere [Seinfeld and Pandis, 2006]. In turn, CO is the major sink for $\mathrm{OH}[\mathrm{Jacob}, 1999]$. Both $\mathrm{O}_{3}$ and $\mathrm{CO}$ are criteria pollutants regulated under the US National Ambient Air Quality Standards.

The major sources of ozone in the troposphere include stratospheric injection and in-situ chemical production, with chemical production comprising approximately $90 \%$ of $\mathrm{O}_{3}$ sources in the Northern Hemisphere [Seinfeld and Pandis, 2006]. Chemical production involves a series of complex interactions involving the oxidation of $\mathrm{CO}$, methane $\left(\mathrm{CH}_{4}\right)$, and nonmethane volatile organic compounds (NMVOCs) in the presence of nitrogen oxides $\left(\mathrm{NOx}=\mathrm{NO}+\mathrm{NO}_{2}\right)$ [Seinfeld and Pandis, 2006]. As the chemical equations below show, in the absence of $\mathrm{NOx}, \mathrm{CO}$ oxidation leads to $\mathrm{O}_{3}$ destruction. The major sinks for $\mathrm{O}_{3}$ are photochemical loss $(\sim 80 \%)$ and dry deposition [Seinfeld and Pandis, 2006].

$$
\begin{array}{ll}
\mathrm{CO}+\mathrm{OH}+\mathrm{O}_{2} \rightarrow \mathrm{CO}_{2}+\mathrm{HO}_{2} & \mathrm{CO}+\mathrm{OH}+\mathrm{O}_{2} \rightarrow \mathrm{CO}_{2}+\mathrm{HO}_{2} \\
\mathrm{HO}_{2}+\mathrm{NO} \rightarrow \mathrm{OH}+\mathrm{NO}_{2} & \underline{\mathrm{HO}_{2}} \underline{\underline{\mathrm{CO}}+\mathrm{O}_{3}} \underline{3} \rightarrow \mathrm{CO}_{2}+\mathrm{O}_{2} \\
\mathrm{NO}_{2}+\mathrm{hv} \rightarrow \mathrm{NO}+\mathrm{O} & \\
\underline{\mathrm{O}+\mathrm{O}_{2}}+\underline{\mathrm{CO} \rightarrow \mathrm{O}_{3}}+\underline{\underline{\mathrm{O}}}+\frac{\mathrm{M}}{\mathrm{O}_{2} \rightarrow \mathrm{CO}_{2}+\mathrm{O}_{3}} &
\end{array}
$$


Carbon monoxide is the product of incomplete combustion and thus has a large anthropogenic source, particularly in the Northern Hemisphere [Holloway et al., 2000; Khalil and Rasmussen, 1990; Seinfeld and Pandis, 2006]. Thus, $\mathrm{O}_{3}$ production in the lower free troposphere of the Northern Hemisphere is largely regulated by anthropogenic sources [Hudman et al., 2008; Martin et al., 2006; Pfister et al., 2006]. Other predominant sources of $\mathrm{CO}$ include biomass burning and in-situ oxidation of $\mathrm{CH}_{4}$ [Holloway et al., 2000; Jacob, 1999]. The main sink for CO is oxidation by $\mathrm{OH}$, ultimately yielding the GHG carbon dioxide $\left(\mathrm{CO}_{2}\right)$ [Jacob, 1999]. Table 1 lists the major sources and sinks of global CO. Carbon monoxide's relatively simple chemistry, well quantified sources and sinks, and atmospheric lifetime of $\sim 2$ months make it a good tracer for both measuring and modeling anthropogenic emissions [Duncan et al., 2007; Kopacz et al., 2010].

Table 1: Sources and sinks of CO, adapted from Seinfeld and Pandis 2006.

\begin{tabular}{|l|c|}
\hline & Range of estimates $\left(\right.$ TG CO $\mathbf{~ y r}^{-1}$ ) \\
\hline Sources & $\mathbf{1 8 0 0}-\mathbf{2 7 0 0}$ \\
\hline Fossil fuel/Industry & $300-550$ \\
\hline Biomass Burning & $300-700$ \\
\hline Oxidation of Hydrocarbons & $600-1600$ \\
\hline Oceans & $20-200$ \\
\hline Vegetation & $60-160$ \\
\hline Sinks & $\mathbf{1 4 0 0}-\mathbf{2 6 0 0}$ \\
\hline OH oxidation & $1400-2600$ \\
\hline Stratosphere & $\sim 100$ \\
\hline Soil uptake & $250-640$ \\
\hline
\end{tabular}

Increases in $\mathrm{NOx}, \mathrm{CH}_{4}$, and $\mathrm{CO}$ concentrations have lead to increases in free tropospheric $\mathrm{O}_{3}$ since pre-industrial times [Hudman et al., 2009]. More recently, divergent trends of tropospheric $\mathrm{O}_{3}$ have been observed over different regions of the Northern Hemisphere [Fusco and Logan, 2003]. Over the past decade, emissions of 
ozone pre-cursors have declined significantly in the US and Europe, while increasing in Asia [Hudman et al., 2009; Vingarzan, 2004]. Figure 1 shows significant decreases in US emissions of $\mathrm{CO}$ and $\mathrm{NO}_{2}$ since 1980. US sources account for approximately $80 \%$ of emissions from North America [Wang et al., 2009]. It is possible that these declines have also resulted in declines of $\mathrm{CO}$ and $\mathrm{O}_{3}$ in the lower free troposphere over the North Atlantic US outflow region. It is also possible that increases in $\mathrm{CO}$ and $\mathrm{O}_{3}$ pre-cursors from Southeast Asia have offset declines in the US and Europe; possibly offsetting US and European emission declines.

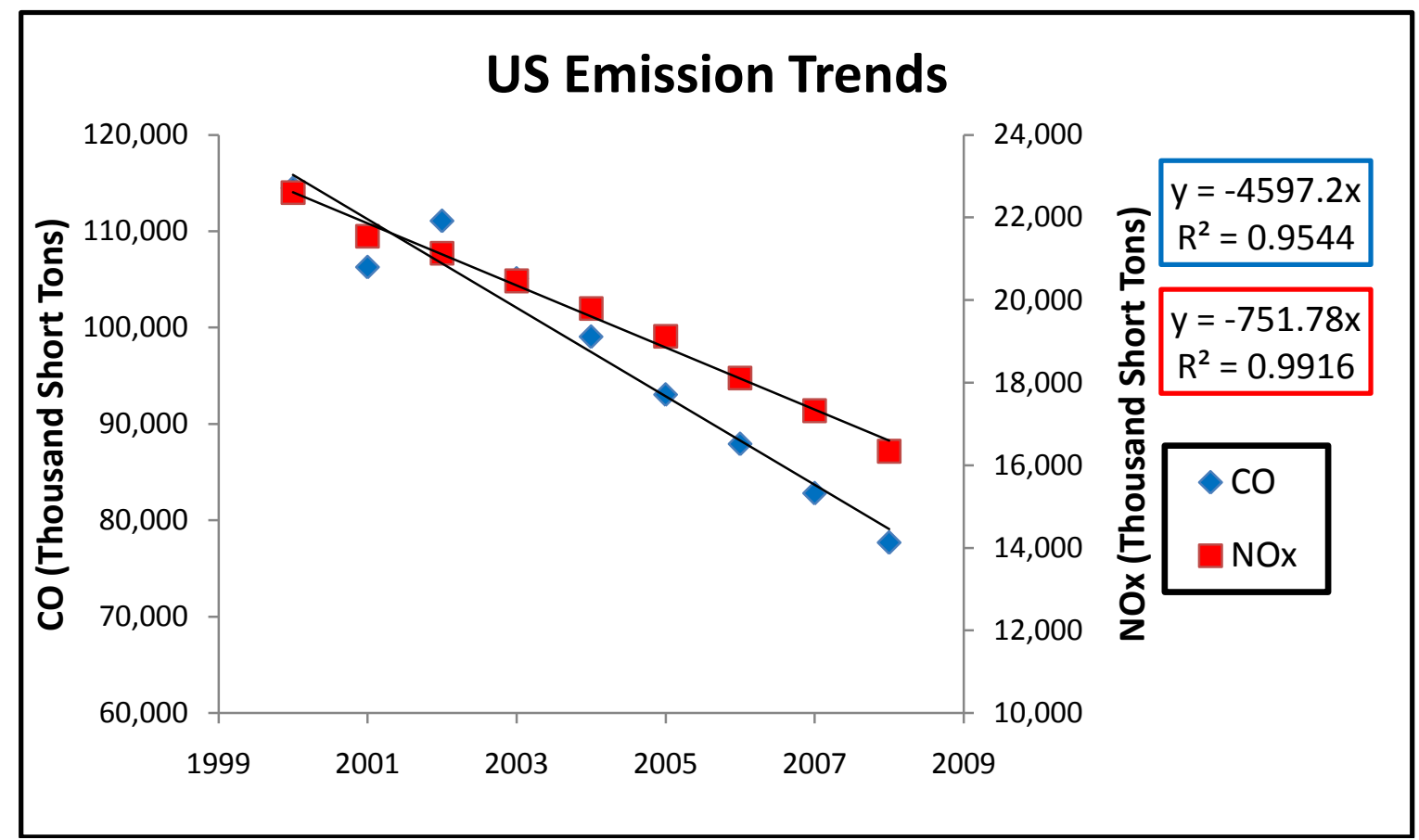

Figure 1: US emission reductions in thousand short tons for $\mathrm{CO}$ and $\mathrm{NO}_{\mathrm{x}}$ from 2000 to 2008. Data available at: http://www.epa.gov/ttnchie1/trends/.

It is now widely recognized that outflow from one continent can impact air quality and background pollutant levels in other continents [R Honrath et al., 2004; Li et al., 2002; L Zhang et al., 2008]. In a study using GEOS-Chem to quantify the North American impact on Europe, Li et al. (2002) found that $20 \%$ of European summer $\mathrm{O}_{3}$ 
violations would not have occurred in the absence of North American anthropogenic emissions. Thus, reduced or increased outflow concentrations from one region have policy implications for a region downwind.

The sparse availability of consistent long-term data of continental outflow often makes it difficult to examine the effects of trends in emissions from a given region. Pico atmospheric monitoring station is a mountain top site located on Pico Island, Azores and is one of only a few such stations located in the remote free troposphere. However, insitu monitoring is subject to equipment failures and seasonal operating limitations. Avoiding such limitations is one of the main advantages to using models and remote sensing instruments. Also, improved coverage and capability in remote sensing instruments will likely increase use of these instruments for long term analysis moving forward. Thus, quantifying the ability of models and satellites to capture in-situ measurements is vital if they are to be used for future policy decisions. Analyzing differences between model output, satellite, and in-situ measurements may also lead to improved understanding of the physical/chemical processes occurring. By comparing insitu, satellite, and model results over a longer period than is done in typical studies we hope to better illustrate each methods advantages and limitations in long term trend analysis and the ability of GEOS-Chem to capture both seasonal and long term trends.

We use a nearly 10 year complete record of summertime (June-August) CO and $\mathrm{O}_{3}$ measurements from the PICO-NARE (Pico Inter-Continental Observatory-North America Regional Export) atmospheric monitoring station (with limited observations in other seasons) and the GEOS-Chem global CTM to analyze how recent emission reductions in the US have impacted $\mathrm{O}_{3}$ and $\mathrm{CO}$ levels in the lower free troposphere at 
Pico, Azores from September 2000 to August 2010. Fall and winter 2000 model runs were included to provide 10 years of model data for trend analysis. Available satellite observations from AIRS/Aqua (Atmospheric Infrared Sounder) for CO and TES (Tropospheric Emission Spectrometer) for $\mathrm{O}_{3}$ are also used in comparison with model and in-situ measurements. A summary of the available data is shown in Table 2; it should be noted that some of the data sets listed were not complete enough for use in trend analysis. This is discussed further in the methods section below.

Table 2: Summary of the available data used in this study. For PICO-NARE data all years are for summer only. For GEOS-Chem, AIRS, and TES yearly coverage is available. A red X indicates only partial records available.

\begin{tabular}{|c|c|c|c|c|c|c|c|c|c|c|c|}
\hline & $\mathbf{2 0 0 0}$ & $\mathbf{2 0 0 1}$ & $\mathbf{2 0 0 2}$ & $\mathbf{2 0 0 3}$ & $\mathbf{2 0 0 4}$ & $\mathbf{2 0 0 5}$ & $\mathbf{2 0 0 6}$ & $\mathbf{2 0 0 7}$ & $\mathbf{2 0 0 8}$ & $\mathbf{2 0 0 9}$ & $\mathbf{2 0 1 0}$ \\
\hline $\begin{array}{c}\text { PICO - } \\
\text { CO }\end{array}$ & & $\mathrm{X}$ & $\mathrm{X}$ & $\mathrm{X}$ & $\mathrm{X}$ & $\mathrm{X}$ & $\mathrm{X}$ & & & $\mathrm{X}$ & $\mathrm{X}$ \\
\hline $\begin{array}{c}\text { PICO } \\
- \text { O }_{3}\end{array}$ & & $\mathrm{X}$ & & $\mathrm{X}$ & $\mathrm{X}$ & $\mathrm{X}$ & $\mathrm{X}$ & & $\mathrm{X}$ & $\mathrm{X}$ & $\mathrm{X}$ \\
\hline $\begin{array}{c}\text { GEOS- } \\
\text { Chem }\end{array}$ & $\mathrm{X}$ & $\mathrm{X}$ & $\mathrm{X}$ & $\mathrm{X}$ & $\mathrm{X}$ & $\mathrm{X}$ & $\mathrm{X}$ & $\mathrm{X}$ & $\mathrm{X}$ & $\mathrm{X}$ & $\mathrm{X}$ \\
\hline $\begin{array}{c}\text { AIRS - } \\
\text { CO }\end{array}$ & & $\mathrm{X}$ & $\mathrm{X}$ & $\mathrm{X}$ & $\mathrm{X}$ & $\mathrm{X}$ & $\mathrm{X}$ & $\mathrm{X}$ & $\mathrm{X}$ & $\mathrm{X}$ \\
\hline $\begin{array}{c}\text { TES- } \\
\mathbf{O}_{3}\end{array}$ & & & & $\mathrm{X}$ & $\mathrm{X}$ & $\mathrm{X}$ & $\mathrm{X}$ & & & $\mathrm{X}$ \\
\hline
\end{tabular}

The remainder of this paper is as follows: section 2 discusses the PICO-NARE station, GEOS-Chem model, AIRS, and TES. Section 3 provides a description of the data analysis methods used and general model performance compared to the Pico data results and satellite retrievals. Model trend results are presented in section 4 and sections 5,6 , and 7 provide a discussion, the conclusions, and recommended future works. 


\section{(2) DATA DESCRIPTION}

\section{(2.1)PICO-NARE}

\section{(2.1.1) Site Description}

Seasonal observations for the period of 2001 to 2010 have been collected at the PICO-NARE station. The station is located at an altitude of $2225 \mathrm{~m}$ on top of Pico Mountain on Pico Island in the Azores, Portugal (38.5 degrees north latitude, 28.4 degrees west longitude)[R Honrath et al., 2004]. Summertime fully automated measurements of $\mathrm{CO}$ and $\mathrm{O}_{3}$ have been collected since 2001 with occasional outages due to power loss and equipment failure. The station is frequently impacted by North American (NA) export, with transport times from 5 to 7 days [Helmig et al., 2008; $R E$ Honrath et al., 2008; Martin et al., 2006; Owen et al., 2006; Pfister et al., 2006]. Numerous studies have analyzed transport of air arriving at Pico station using Hybrid Single-Particle Lagrangian Integrated Trajectories (HYSPLIT) and FLEXPART $[R$ Honrath et al., 2004; Lapina et al., 2006; Owen et al., 2006]. Analysis revealed that Pico station is frequently impacted by outflow from the eastern U.S. as evidenced by enhanced $\mathrm{CO}$ and $\mathrm{O}_{3}$ arriving at Pico and backward trajectory analysis.

One potential problem with mountaintop measurements is uplifting by synoptic winds and buoyant upslope flow from radiant heating of the earth's surface. This creates the potential for marine boundary layer air to be sampled rather than free troposphere (FT) air. Extensive analysis of orographic flows conducted in 2004 revealed that the station is impacted by buoyant upslope flows and mechanically forced wind driven 
upslope flows $24 \%$ and $15 \%$ of the days respectively for the summer period[Kleissl et al., 2007]. The period from October thru April is more heavily impacted by synoptic winds and mechanical uplift, the probability of sampling marine boundary layer ranges from 35 to $60 \%$ per month and $<20 \%$ for May thru September[Kleissl et al., 2007].

Measurements of isoprene (emitted from vegetation more than $700 \mathrm{~m}$ below the station) and n-butane (a cooking fuel used on Pico) revealed that even on days when the station is impacted by uplifting, the air did not originate from the surface[Kleissl et al., 2007] . Thus, Pico station is an ideal location for sampling the lower free troposphere.

\section{(2.1.2) Measurement Methods}

Carbon monoxide measurements and ozone measurements are described by Honrath et al. [2004] and summarized here. For CO, a Thermo Environmental Inc. (TEI), 48C-TL trace level gas filter correlation $\mathrm{CO}$ analyzer with a palladium catalyst was used. Instrument sensitivity for the period from 2001-2003 was $+/-3 \%$ and the instrument precision was $+/-8 \%$. Measurement precision (2- $\sigma)$ was $+/-8$ ppbv or better, with $+/-3 \%$ variation from 2001 to 2003 . Ozone measurements were via ultraviolet absorption (TEI Model 49C) and were found to be $3.9+/-0.3 \%$ low compared to NIST reference standard. Due to damage the instrument was replaced with an identical one and was found to be $3.5+/-0.3 \%$ lower than the 2001 instrument. All measurements were multiplied by 1.039 and measurements from 2003 on were multiplied by another 1.035. One minute averages were found to have a measurement precision that was usually within 1 ppbv. 


\section{(2.2) AIRS/AQUA}

The Atmospheric Infrared Sounder (AIRS) was launched onboard the AQUA satellite May 4, 2002. AIRS is polar orbiting nadir-viewing thermal IR sounder with cloud clearing capability and retrieves $\mathrm{CO}$ at $4.7 \mu \mathrm{m}$ with $70 \%$ daily global coverage; $100 \%$ between $45^{0}$ and $80^{\circ}$ LON [McMillan et al., 2005; Yurganov et al., 2008]. We use AIRS Level 3 version 5 monthly data obtained from Giovanni, Goddard Earth Sciences Data and Information Services Center (GES DISC), data is available at http://disc.sci.gsfc.nasa.gov/giovanni\#instances [Acker and Leptoukh, 2007]. Level 3 data includes only data that has undergone rigorous processing and is available with no significant requirement for data manipulation. As was done in prior studies, we include only AIRS measurements with $>0.5$ degrees of freedom [Fisher et al., 2010]. Previous comparison of AIRS with in-situ measurements reveals a positive bias of $\sim 10 \%$ in the Northern Hemisphere [Fisher et al., 2010; Kopacz et al., 2010]. Retrievals were obtained

for the area covering the same horizontal grid as GEOS-Chem $\left(-32.5^{0}\right.$ to $-27.5^{0} \mathrm{~W}$ and $36^{0}$ to $40^{\circ} \mathrm{N}$ ) centered at $802 \mathrm{hPa}$ (roughly $2.2 \mathrm{~km}$, the same elevation as Pico station).

Since both the Pico data and GEOS-Chem use both day and night values we use both day and night retrievals for AIRS.

\section{(2.3) TES/Aura}

The Tropospheric Emission Spectrometer (TES) was launched in July of 2004 aboard the EOS Aura. Data was obtained from Giovanni online data system, developed and maintained by the NASA GES DISC as previously mentioned. TES is nadir viewing in a polar orbiting sun synchronous orbit on the same track as AIRS/Aqua with an local 
crossing time of 01:45 and 13:45 [L Zhang et al., 2010]. TES obtains global coverage every 16 days, however, near daily coverage is achieved for our area of interest. The average time between the validated measurements used in this study is approximately three days. We use available data for the period covering 2005 to 2010 . The data for 2008 - 2009 was not available, further limiting our ability to provide useful comparison to modeled $\mathrm{O}_{3}$ results. The level three data comes pre-processed and negative values were removed. Previous comparison with in-situ measurements show that TES has a positive bias of $5.3 \mathrm{ppbv}$ for ozone [L Zhang et al., 2010].

\section{(2.4) GEOS-Chem}

\section{(2.4.1) Model Description}

We use the global 3D GEOS-Chem chemical transport model (CTM) version 803-01 (http://acmg.seas.harvard.edu/geos/index.html) driven by assimilated meteorology from Goddard Earth Observing System (GEOS) from the NASA Data Assimilation Office (DAO). The original model description is provided by Bey et al. (2001) with updates described by Duncan and Fisher [Bey et al., 2001; Duncan et al., 2007; Fisher et al., 2010]. GEOS-Chem simulates atmospheric chemistry using 43 tracers with over 80 chemical species and 300 reactions. The model is initiated with a "restart" file containing concentrations for each species in each grid box. To allow for model initialization and stabilization, a "spin-up" period of typically 6 to 12 months is used. A "full chemistry" NOx-Ox-hydrocarbon simulation with SMVGEAR chemical solver developed by Jacobson et al. was used [Jacobson and Turco, 1994]. Photolysis rate constants in 
GEOS-CHEM are calculated with the Fast-J algorithm originally described by Wild et al. (2000).

Significant changes from previous versions include updated chemistry and photolysis rates as mentioned above, linearized stratospheric ozone (Linoz) chemistry package, and updated emissions databases. "Linoz is a first-order Taylor expansion of stratospheric chemical rates in which the ozone tendency has been linearized about the local ozone mixing ratio, temperature, and the overhead column ozone density" [McLinden et al., 2000]. Previous versions used the synthetic ozone (SYNOZ) passive ozone tracer. The SYNOZ method applies a uniform flux for all areas of the tropopause whereas the Linoz method varies spatial distribution of cross-tropopause exchange and is thus more realistic. Emission inventory updates include addition of the 2005 Environmental Protection Agency (EPA) National Emissions Inventory Database (NEI2005), and MEGAN v2.1 biogenic emissions. The MEGAN inventory includes emission rates for isoprene, methylbutenol, and seven monoterpene compounds $(\alpha-$ pinene, $\beta$-pinene, limonene, myrcene, sabinene, 3-carene and ocimene); an original description is provided by Guenther with updates by Sakulyanontvittaya [Guenther et al., 2006; Sakulyanontvittaya et al., 2008].

Model emissions for $\mathrm{CO}$ include fossil fuel/industry, biofuel, biogenic, biomass burning, and oxidation of $\mathrm{CH}_{4}$. Global emissions for all anthropogenic emissions are provided by the EDGAR emissions inventory with a base year of 1998 [Olivier and Berdowski, 2001]. The EDGAR inventory is overwritten by several regional inventories, including: EPA NEI 2005 for the U.S.[EPA, 2005], CAC for Canada [Canada, 2005], BRAVO for portions of Mexico and the Gulf of Mexico[Kuhns et al., 2005], EMEP for 
Europe [Vestreng and Klein, 2002], and Streets for Asia [Streets et al., 2003]. Biofuel emissions are from Yevich \& Logan which is overwritten by EPA NEI 2005 and Streets [Yevich and Logan, 2003].

Annual scale factors are applied globally to $\mathrm{NO}_{\mathrm{x}}, \mathrm{CO}$ and $\mathrm{SOx}$ following the approach implemented by van Donkelaar et al. (2008) which builds upon the method used by Bey et al. (2001), and Park et al. (2004). The basic method is to scale emissions according to $\mathrm{CO}_{2}$ trends obtained from the Carbon Dioxide Information Analysis Center using total solid and liquid $\mathrm{CO}_{2}$ [van Donkelaar et al., 2008]. Where available this data is overwritten by regional government statistics. Trend data for major sources is derived from: Environment Canada National Pollutant Release Inventory Trends for Canada, EPA Acid Rain Program and National Emissions Inventory for the U.S., European Monitoring and Evaluation Program for Europe, and the Regional Emission inventory in Asia.

We use GFED v2 monthly inventory for 2001-2008 as described by van der Werf [van der Werf et al., 2006]. The GFED inventory uses fire counts derived from the Moderate Resolution Imaging Spectrometer to determine the timing and location of fires. Emissions are determined based on area burned and vegetation type. One known problem with the GFEDv2 inventory is the misallocation of Alaskan fires as savanna type which is not the typical Alaskan fire. For 2009 and 2010, GFEDv2 2008 was used. We feel this configuration provides the best available model estimate for actual conditions over the study period with the available data. Table 3 provides model anthropogenic and biomass burning $\mathrm{CO}$ emissions for various regions of the Northern Hemisphere over the time period covered in this study. The model shows significant anthropogenic CO 
declines for North America and Europe but increases from Asia. There is also a decline in $\mathrm{CO}$ from biomass burning over the time period covered.

Table 3: GEOS-Chem $\mathrm{CO}$ sources for various locations and sources. Values are $\mathrm{Tg} \mathrm{CO}$ year $^{-1}$. The years 2000 and 2010 are omitted because the first 8 months of 2000 were in the spin-up period and only 8 months of 2010 are available.

\begin{tabular}{|c|c|c|c|c|c|c|}
\hline & \multicolumn{3}{|c|}{ ANTHROPOGENIC } & \multicolumn{2}{c|}{ BIOMASS BURNING } \\
\hline YEAR & $\begin{array}{c}\text { Northern } \\
\text { Hemisphere }\end{array}$ & $\begin{array}{c}\text { North } \\
\text { America }\end{array}$ & Europe & Asia & $\begin{array}{c}\text { Northern } \\
\text { Hemisphere }\end{array}$ & $\begin{array}{c}\text { North } \\
\text { America }\end{array}$ \\
\hline $\mathbf{2 0 0 1}$ & 436.48 & 97.27 & 45.11 & 245.87 & 202.62 & 8.67 \\
\hline $\mathbf{2 0 0 2}$ & 447.94 & 99.89 & 42.81 & 255.98 & 230.88 & 21.30 \\
\hline $\mathbf{2 0 0 3}$ & 460.27 & 95.50 & 41.56 & 272.86 & 246.49 & 33.94 \\
\hline $\mathbf{2 0 0 4}$ & 461.08 & 90.59 & 41.57 & 278.12 & 200.96 & 23.24 \\
\hline $\mathbf{2 0 0 5}$ & 460.14 & 86.26 & 40.00 & 281.77 & 215.97 & 20.76 \\
\hline $\mathbf{2 0 0 6}$ & 460.68 & 82.98 & 38.21 & 286.16 & 180.87 & 15.46 \\
\hline $\mathbf{2 0 0 7}$ & 455.88 & 82.99 & 35.43 & 286.16 & 219.55 & 15.31 \\
\hline $\mathbf{2 0 0 8}$ & 457.24 & 83.23 & 35.56 & 287.01 & 180.89 & 13.84 \\
\hline $\mathbf{2 0 0 9}$ & 455.88 & 83.00 & 35.43 & 286.16 & 180.00 & 13.83 \\
\hline Trend & $\mathbf{+ 1 . 6 1}$ & $\mathbf{- 2 . 3 3}$ & $\mathbf{- 1 . 2 7}$ & $\mathbf{+ 4 . 8 2}$ & $\mathbf{- 5 . 2 4}$ & $\mathbf{- 0 . 7 8}$ \\
\hline
\end{tabular}

\section{(2.4.2) Model runs}

For the period covering 2001 to 2004 we use meteorology driven by GEOS-4 (Goddard Earth Observing System) from the NASA GMAO (Global Modeling and Assimilation Office). Original GEOS-4 product is gridded on $0.5^{0} \times 0.667^{0}$ resolution and 55 hybrid pressure-sigma levels which we regrid to $4^{0} \times 5^{0}$ and 30 vertical levels. For the period covering 2005 to 2010 we use GEOS-5 meteorology with the same horizontal resolution but 72 hybrid pressure-sigma levels which are reduced to 47 levels. Both vertical levels used in this study are centered at $2.2 \mathrm{~km}$, the same altitude as the Pico station. A one year spin-up was used for both meteorological fields. Both 24 hour average concentrations for global coverage and 4 hour average timeseries data centered over Pico were archived. We use a time step for transport and convection of 30 minutes and a 60 minute time step for chemistry. 
For sensitivity studies regarding the impact that North American fossil fuel emissions have on concentrations at Pico, fossil fuel emissions were shut off from $15^{\circ}$ to $88^{\circ} \mathrm{N}$ LAT and from $50^{\circ}$ to $165^{\circ} \mathrm{W}$ LONG. This area includes the US, Canada, and Mexico. The model was run again for the same timeframe with all other settings set exactly as the initial run. Spin-up, archiving and processing were also performed the same as the original run.

\section{(3) Data Analysis Methods}

When processing the Pico data into 24 hour averages, only days with more than three data points were used, such occurrences were infrequent and most summer time data included 24 data points per day. We use hourly averages from Pico which are then averaged into 24 hour averages. For comparison with the Pico data to model and satellite output, 24 hour averages were used. Satellite data had 2 data points per day, one in the morning and one in the evening. GEOS-Chem output was archived at 4 hour intervals and thus had 6 data points per 24 hour average. The 24 hour averages were then used to calculate either monthly or seasonal (winter-Dec. to Feb, spring-Mar. to May, summerJun. to Aug., fall-Sept to Nov.) averages for comparison. It is important to note that in order to directly compare satellite and model observations one would apply the averaging kernel used in the satellite retrieval [L Zhang et al., 2006]. The averaging kernel is a weighting function which determines concentrations at selective vertical intervals based on satellite column measurements. Applying the averaging kernel to the model column concentration allows one to determine what the satellite output would be if the model column concentration were the actual atmospheric conditions. That was not done in this 
study and values presented here represent the independent value obtained from each source.

For seasonal averages, only periods with adequate measurements from all three months were used. For example, 2001 measurements did not begin until July and thus summer 2001 was dropped from the analysis. The determination for an adequate amount of in-situ data for any given month was somewhat arbitrary given the variability in the data. Generally, if a month included fewer than 15 days or was too heavily weighted towards one portion of the month it was not used. For example, March 2005 had 5 days all at the end of the month and would not be included in trend analysis. This did not occur for any summer months.

\section{(4) General Model Performance}

Two basic methods were used to assess the model performance in comparison with Pico data. Timeseries plots of seasonal and annual periods were used to gain a general understanding of model performance. Various available options in the model were assessed for the ability to capture in-situ measurements in both magnitude and variability. Certain previously identified North American pollution transport events arriving at Pico which included both biomass burning and anthropogenic events were used. Two horizontal resolutions are available in the model, $2^{\circ} \times 2.5^{\circ}$ or $4^{\circ} \times 5^{\circ}$. It was generally thought that the $2^{\circ} \times 2.5^{\circ}$ resolution would better capture results from the data, particularly transport events from North America. Figure 2 is a timeseries plot for August of 2009 CO. Large spikes in the data are attributed to pollution transport events, although none of the events here have been evaluated as yet. For the summer of 2009 the 
$2^{\circ} \times 2.5^{\circ}$ was +1.06 ppbv with a range of +23.1 to -27.8 compared to the $4^{\circ} \times 5^{\circ}$ horizontal grid resolution. The main focus is to illustrate that little difference can be seen between the two resolutions; and given the addition computational time required for the finer resolution (approximately 40 days for ten years of $2^{\circ} \times 2.5^{\circ}$ vs. 10 days for $4^{\circ} \times 5^{\circ}$ ); the $4^{\circ} \times 5^{\circ}$ horizontal resolution was used. Rastigejev et al. (2010) found similar results when looking at the ability of global models to track pollution plumes over long distances [Rastigejev et al., 2010]. In general, Eulerian models suffer from numerical dispersion of pollution plumes regardless of the grid size chosen.

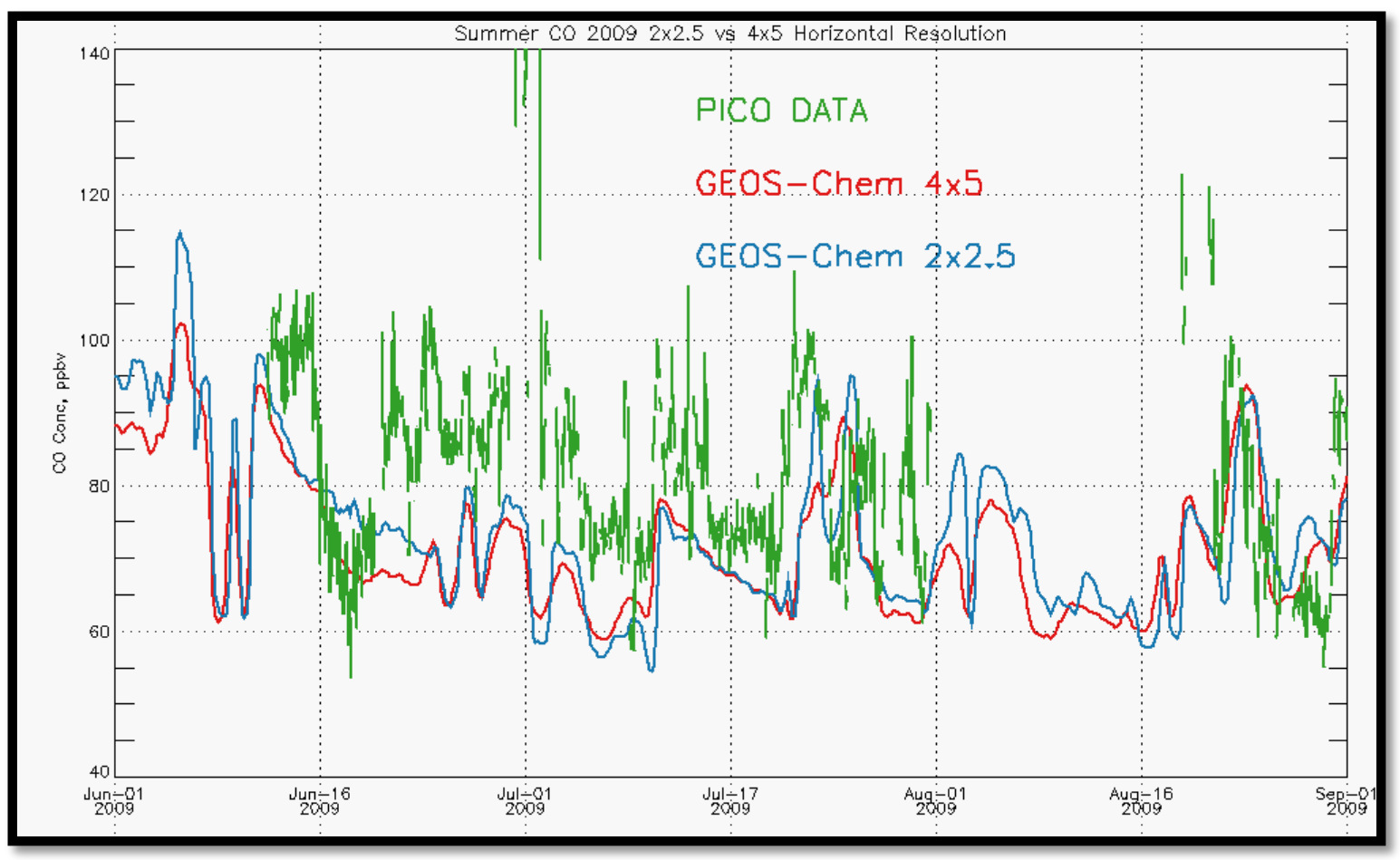

Figure 2: Timeseries plot for GEOS-Chem $2^{\circ} \times 2.5^{\circ}$ in blue and GEOS-Chem $4^{\circ} \times 5^{\circ}$ in red for summer 2009 . Although the $2^{\circ} \times 2.5^{\circ}$ shows slightly more variability, for our purposes it yields little benefit in capturing the magnitude of $\mathrm{CO}$.

As mentioned previously, GEOS-Chem has several biomass burning options available. Several years of summer CO were analyzed to determine what effect the choice of various biomass burning inventories have on model results for Pico station. 
Figure 3 shows that the model is relatively insensitive to biomass burning at Pico and the N. Atlantic in general. For the time period shown in the left panel of Figure 3, using GFED results in $+4.16+/-3.24$ ppbv $\mathrm{CO}$ when compared with using no biomass burning emissions. Again, this is due to numerical diffusion of pollution plumes and the coarse model resolution. Rastigejev et al. (2010) estimate that the model resolution would have to increase to $3 \times 3 \mathrm{~km}$ in order to effectively capture the long range transport of such plumes.

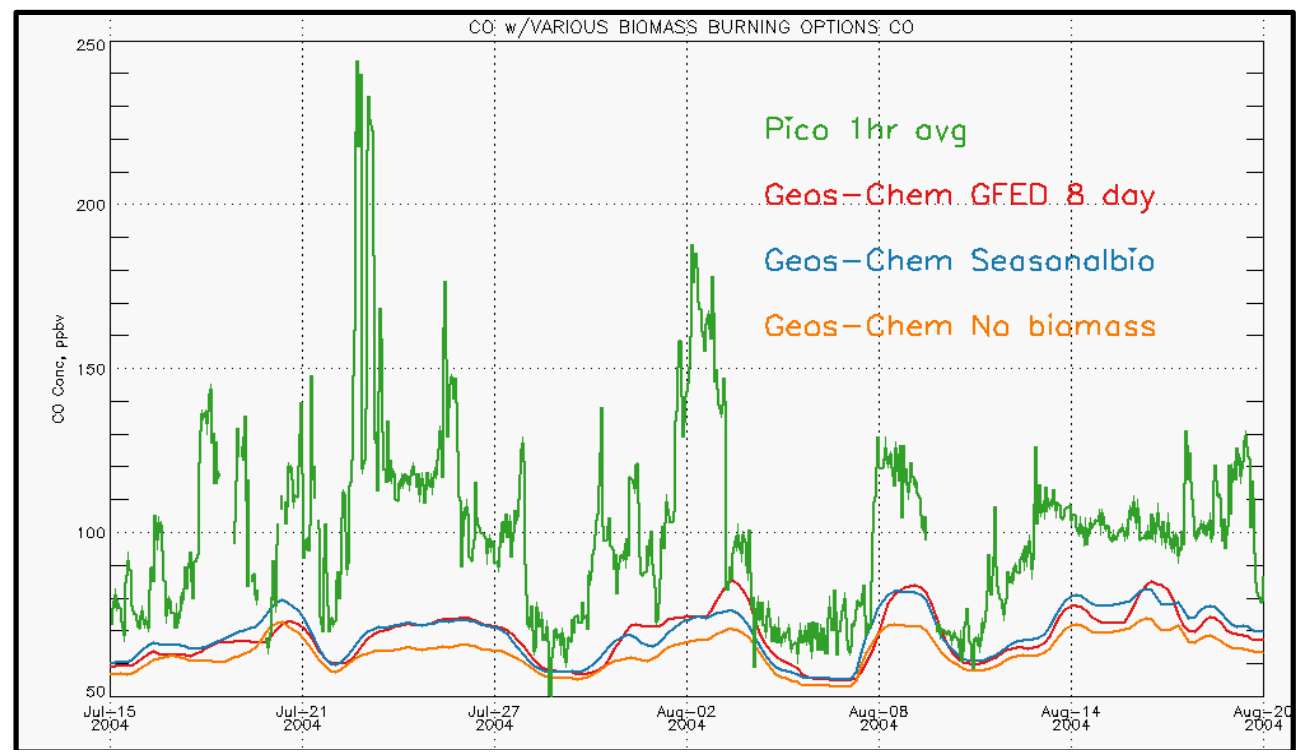

Figure 3: The top panel shows timeseries at Pico from July 15, 2004 to August 20, 2004 with three different biomass burning events.

One must also assess the models ability to capture the seasonal variation and long term "trends" in the data. Figure 4 shows a timeseries plot for the full record of both $\mathrm{CO}$ and $\mathrm{O}_{3}$. As can be seen, the model captures the seasonal cycles observed in the data quite well. The model is low for $\mathrm{CO}$ as has been found in other studies [Bey et al., 2001; Duncan and Logan, 2008; Duncan et al., 2007]. Depending on where one is looking, model $\mathrm{CO}$ can range from 10 to $50 \mathrm{ppbv}$ low compared to in-situ measurements. For 
ozone the model captures the temporal variation and magnitude quite well, although it lacks the magnitude of variation seen in the data; this is also consistent with previous results which show the model is typically within 10 ppbv of $\mathrm{O}_{3}$ measurements[Bey et al., 2001; Choi et al., 2008]. Figure 5 shows model results plotted against Pico data along with a 1:1 ratio line. Again, for $\mathrm{CO}$ we see that the model is consistently low, particularly at higher values of $\mathrm{CO} ; y=0.56 x \mathrm{R}^{2}=0.68$. For ozone the model is higher than the data at concentrations below $\sim 50 \mathrm{ppbv}$ and lower than the data for concentrations above $\sim 50$ ppbv; $y=0.36 x \mathrm{R}^{2}=0.29$. Again, this demonstrates that the model does not capture the variability seen in the Pico $\mathrm{O}_{3}$ data. A seasonal breakdown of similar 1:1 plots as those shown in Figure 5 is provided in the appendix.

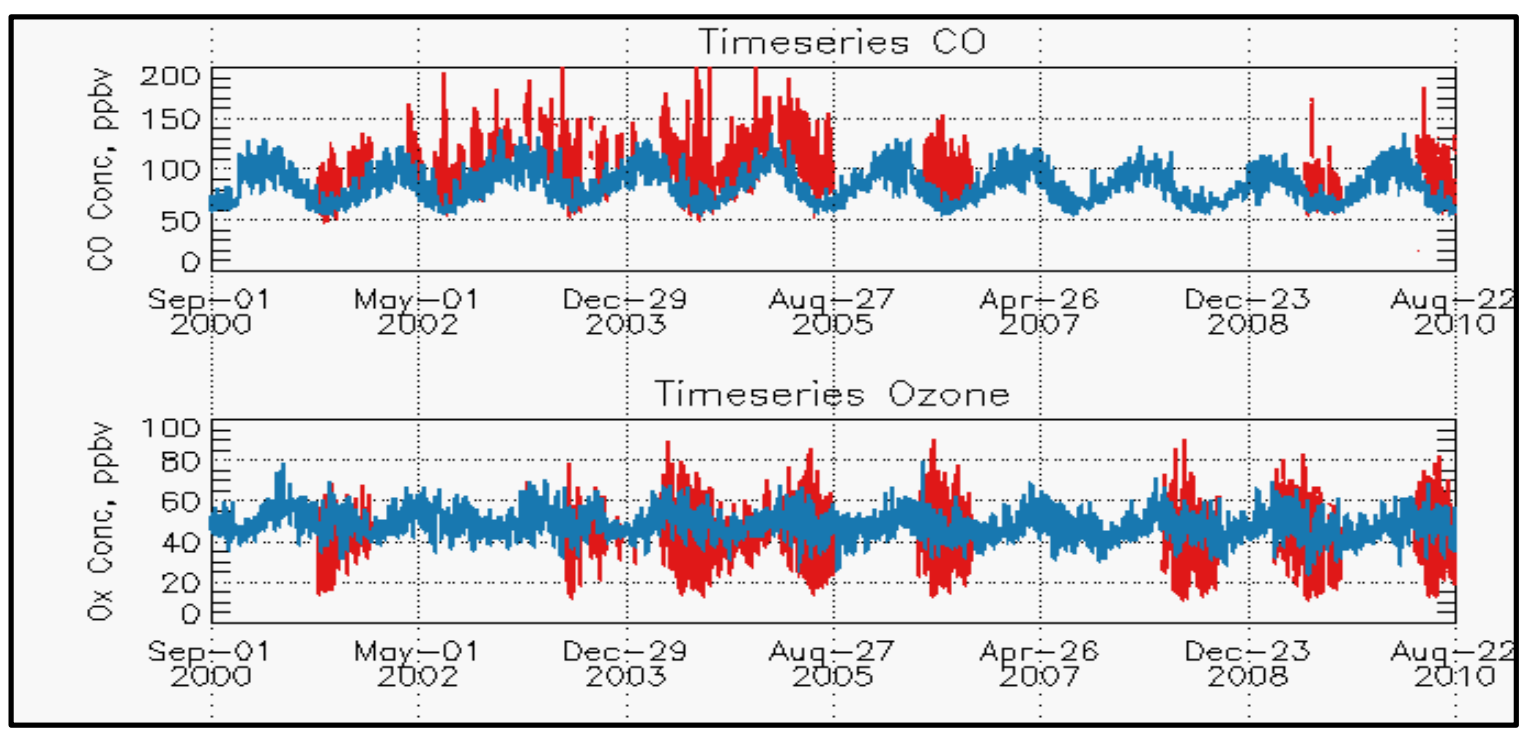

Figure 4: Timeseries plot of all available data points covering the full record of all available data. $\mathrm{CO}$ (top), $\mathrm{O}_{3}$ bottom, 1 hour Pico data (red), 4 hour GEOS-Chem data (blue). 


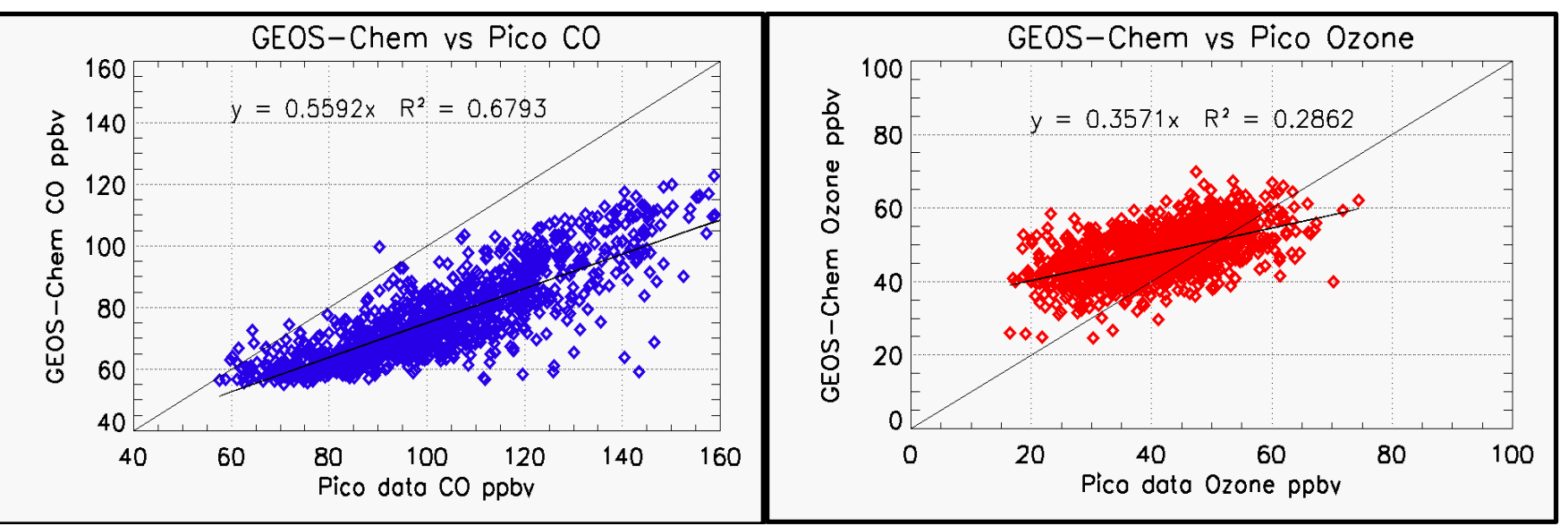

Figure 5: Corresponding 24 hour averages for GEOS-Chem vs. Pico data for CO $(n=1160)$ and ozone $(n=1239)$. The 1:1 line represents perfect correlation.

For the satellite, model, data comparison, we used the period September 2004 to August 2005 as this provided the best available full year record for all data sets. This was done to analyze their ability to capture the seasonal cycles since we analyze seasonal trends, and to better observe differences in the variability of the three data sets. Figure 6 shows the results for the seasonal cycle of $\mathrm{O}_{3}$ (left) and $\mathrm{CO}$ (right) for 1 year based on available daily averages. March was a particularly sparse month for Pico data, with only five days available $\left(27^{\text {th }}-31^{\text {st }}\right)$. June 2005 resulted in no retrieval for TES data and September and October 2004 had only 3 TES data points each.

For ozone both GEOS-Chem and TES are consistently high showing the least amount of agreement in winter and best agreement in summer and fall. With respect to $\mathrm{CO}$ the model is consistently low particularly during the spring. AIRS shows better overall agreement, however, it is low in the spring and high in the summer and fall. All three sets of data display the characteristic cycle of peaking in late spring and reaching a minimum in late summer/fall. Table 4 shows the minimum and maximum values and timing of those values for the data used in Figure 6. For GEOS-Chem there is an 
apparent discrepancy in the timing of minimum ozone. This may be an artifact from the fact that the period covered overlaps the switch from GEOS-4 to GEOS-5 meteorology.
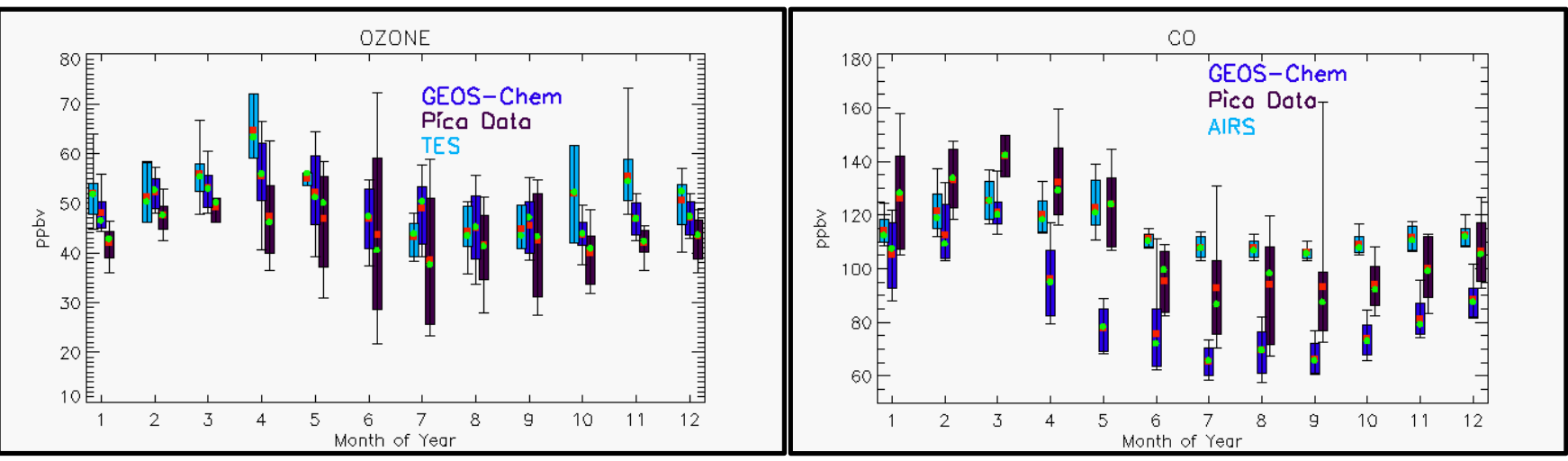

Figure 6: Seasonal cycle in ozone (left) and CO (right) based on 24 hour averages, $\mathrm{x}$ axis numbers correspond to the month of year (i.e. 1 = January). The mean and median are represented with red and green dots respectively.

Table 4: Minimum and maximum values for each respective data set based on monthly averages of 24 hour averaged concentrations for SEP 04 to AUG 05.

\begin{tabular}{|l|l|l|l|l|}
\hline DATA/SOURCE & \multicolumn{2}{|c|}{ CO } & \multicolumn{2}{c|}{ Ozone } \\
\hline & \multicolumn{1}{|c|}{ MIN } & MAX & MIN & MAX \\
\hline Pico Data & 92.18 AUG & 142.05 MAR & $38.56 \mathrm{JUL}$ & 49.07 MAR \\
& & & & \\
\hline GEOS-Chem & 66.33 SEP & 121.08 MAR & 43.54 OCT & 55.51 APR \\
\hline Satellite & 106.00 SEP & 125.47 MAR & $43.20 \mathrm{JUL}$ & $64.61 \mathrm{APR}$ \\
\hline
\end{tabular}

There is some potential for discrepancy due to the use of GEOS-4 and GEOS-5

assimilated meteorology. In particular, GEOS-4 has a coarser vertical resolution

compared to GEOS-5 and uses a deep convection scheme described by Zhang et al.

(1995) where GEOS-5 uses a relaxed Arakawa-Schubert scheme described by Moorthi et

al. (1992) [Moorthi and Suarez, 1992; G J Zhang and Mcfarlane, 1995]. While it would

be ideal to use one GEOS version for the entire run, availability of GEOS 4 or GEOS 5

does not cover the entire period of interest. A two year period of overlap, 2005 thru

2006, revealed that GEOS-5 driven results were on average 1.3 ppbv higher for CO with

a range of +14.1 to -17.5 ppbv. Figure 7 and Figure 8 show plots for GEOS-4 vs. GEOS- 
5. The largest difference (GEOS5-GEOS4) is seen during the spring period $(+1.50+/-$ $3.77 \mathrm{ppbv}$ average $1-\sigma)$ with summer being the period of best agreement $(-0.03+/-2.44$ ppbv average 1- $\sigma$ ). For ozone, GEOS- 5 averages -1.68 ppbv lower than GEOS 4 with a range of +14.0 to -14.4 ppbv. No significant difference in the magnitude of $\mathrm{O}_{3}$ discrepancies was noted between the various seasons.

It is also noted that there is a difference between the mean weighted $\mathrm{OH}$ concentrations between the two meteorological databases as shown in Table 5. GEOS-5 is consistently higher than GEOS-4; this should result in lower CO due to increased oxidation which is inconsistent with our results of higher $\mathrm{CO}$ when using GEOS-5. With higher $\mathrm{OH}$ one might also expect lower $\mathrm{O}_{3}$, since $\mathrm{HOx}\left(\mathrm{OH}+\mathrm{HO}_{2}\right)$ is a minor loss source for ozone in the remote troposphere [Jacob, 1999]. This is consistent with our findings of lower $\mathrm{O}_{3}$ with GEOS-5.

Table 5: Annual mean weighted GEOS-Chem $\mathrm{OH}$ concentration [1e5 molec/cm3]

\begin{tabular}{|c|c|c|c|}
\hline YEAR & GEOS-4 & GEOS-5 & GEOS-5 - GEOS-4 \\
\hline $\mathbf{2 0 0 4}$ & 11.83 & 13.26 & 1.43 \\
\hline $\mathbf{2 0 0 5}$ & 11.87 & 13.07 & 1.20 \\
\hline $\mathbf{2 0 0 6}$ & 12.60 & 12.59 & 0.46 \\
\hline
\end{tabular}

Plots for GEOS-4 vs. GEOS-5 for 2005 and 2006 are shown in Figure 7. Results mimic GEOS-Chem vs. Pico data, with GEOS-4 being low for CO, particularly at higher values and GEOS-4 $\mathrm{O}_{3}$ being high at lower concentrations and low at higher concentrations. Looking at the concentrations in the trend plots reveals that any affect of switching from GEOS-4 to GEOS-5 will most likely result in a higher bias for $\mathrm{CO}$, thus the model $\mathrm{CO}$ trends are more likely to be underestimated. For $\mathrm{O}_{3}$ any model trend under $\sim 50 \mathrm{ppbv}$ is likely to be overestimated since GEOS-5 results are lower than GEOS-4 for 
that concentration range. Thus, the model trends for every season except spring may be a slight overestimate. However, based on the average difference (GEOS-5 - GEOS-4) of 1.3 ppbv for $\mathrm{CO}$ and $-1.7 \mathrm{ppbv}$ for $\mathrm{O}_{3}$ previously reported, any such impact is likely to be negligible. Figure 8 shows timeseries plots for $\mathrm{CO}$ and $\mathrm{O}_{3}$ for 2005 through October 2006, indeed, little difference is noted between the two meteorological fields for both chemical species.

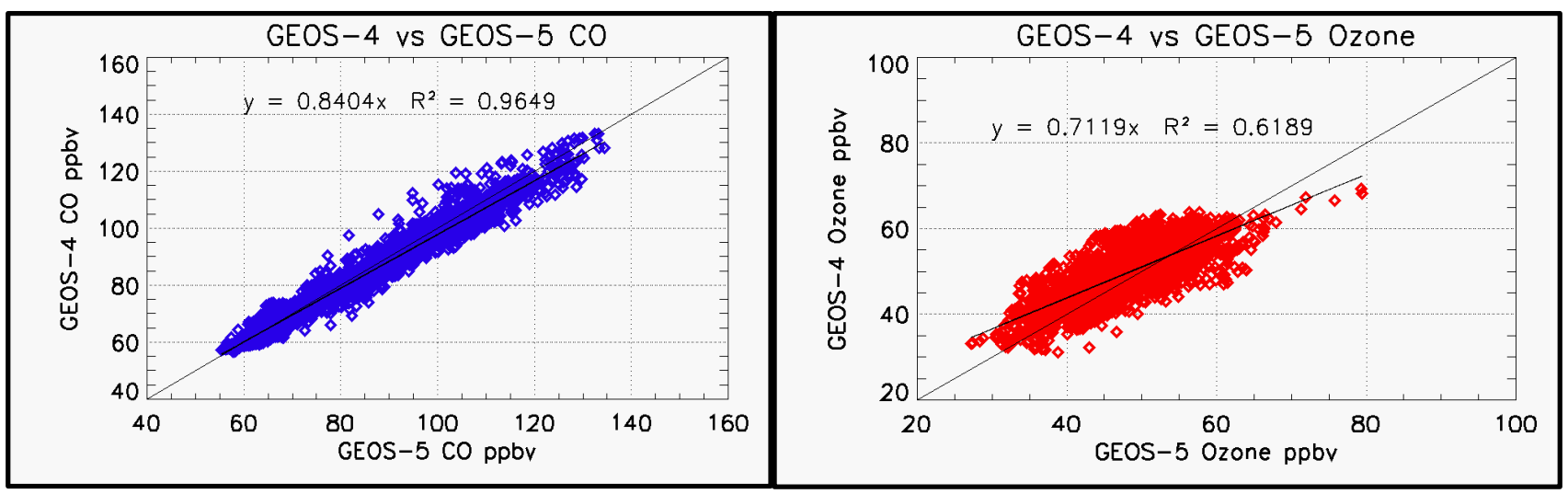

Figure 7: Comparison of GEOS-4 and GEOS-5 assimilated meteorology for CO (left) and $\mathrm{O}_{3}$ (right) from 2005 to 2006 . GEOS-4 and GEOS-5 match quite well, particularly for $\mathrm{CO}$.

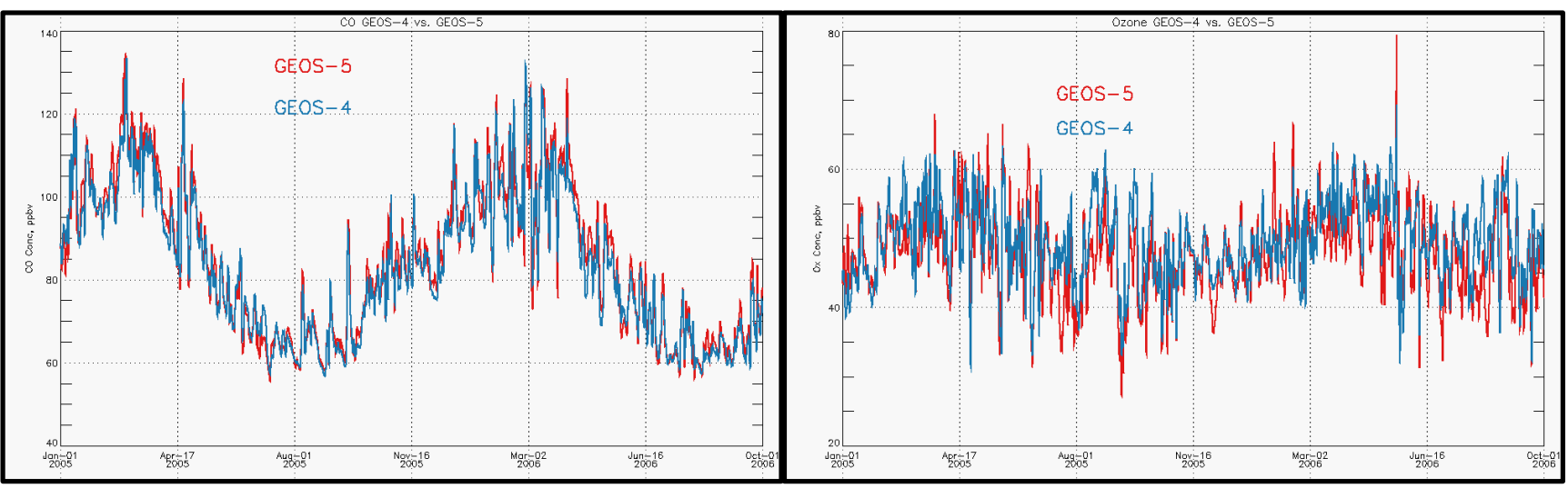

Figure 8: Timeseries plots comparing GEOS-4 (blue) to GEOS-5 (red) for both CO (left) and ozone (right). 


\section{(5) Trend Results}

\section{(5.1) With North American Emissions}

The lack of available data prevents us from specifically declaring any formal trends; however, based on the analysis of model performance we can gain insight into the direction of $\mathrm{CO}$ and $\mathrm{O}_{3}$ concentrations in the lower FT over Pico. Obviously, the most rigorous analysis has covered the summer period, thus, it is summer results which provide the highest confidence. We have shown that the model does capture the seasonal cycle of $\mathrm{CO}$ and $\mathrm{O}_{3}$, however, additional data for seasons other than summer would improve our confidence in results for fall, winter and spring.

Seasonal averages based on 24 hour averages are shown in Figures 9 and 10. Fall is the season which shows the largest declines in both $\mathrm{CO}$ and $\mathrm{O}_{3}$ for model results; for $\mathrm{CO}, \mathrm{AIRS}$ also shows the largest indicated decline is in the fall. In other seasons, both GEOS-Chem and AIRS show more moderate declines in CO. Model results for $\mathrm{O}_{3}$ also show declines in all seasons, although winter results are essentially flat. As was seen with $\mathrm{CO}$, fall is the season showing the largest indicated decline in $\mathrm{O}_{3}$, with spring and summer showing slightly more moderate declines. Pico data corroborates model results of declining $\mathrm{O}_{3}$ in the summer season. 


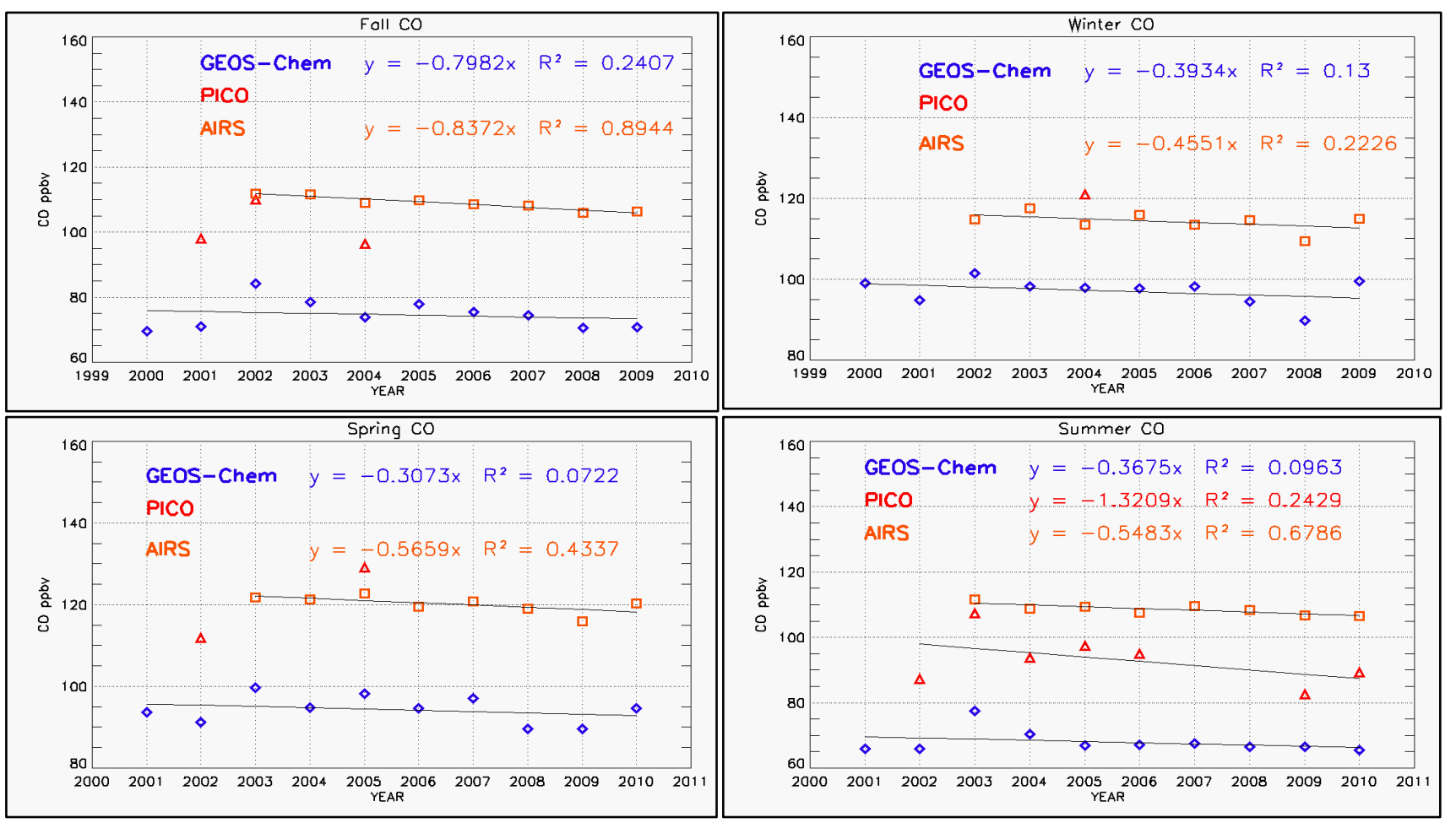

Figure 9: Seasonal modeled trends for $\mathrm{CO}$ at Pico station. All results indicate declines in all seasons.

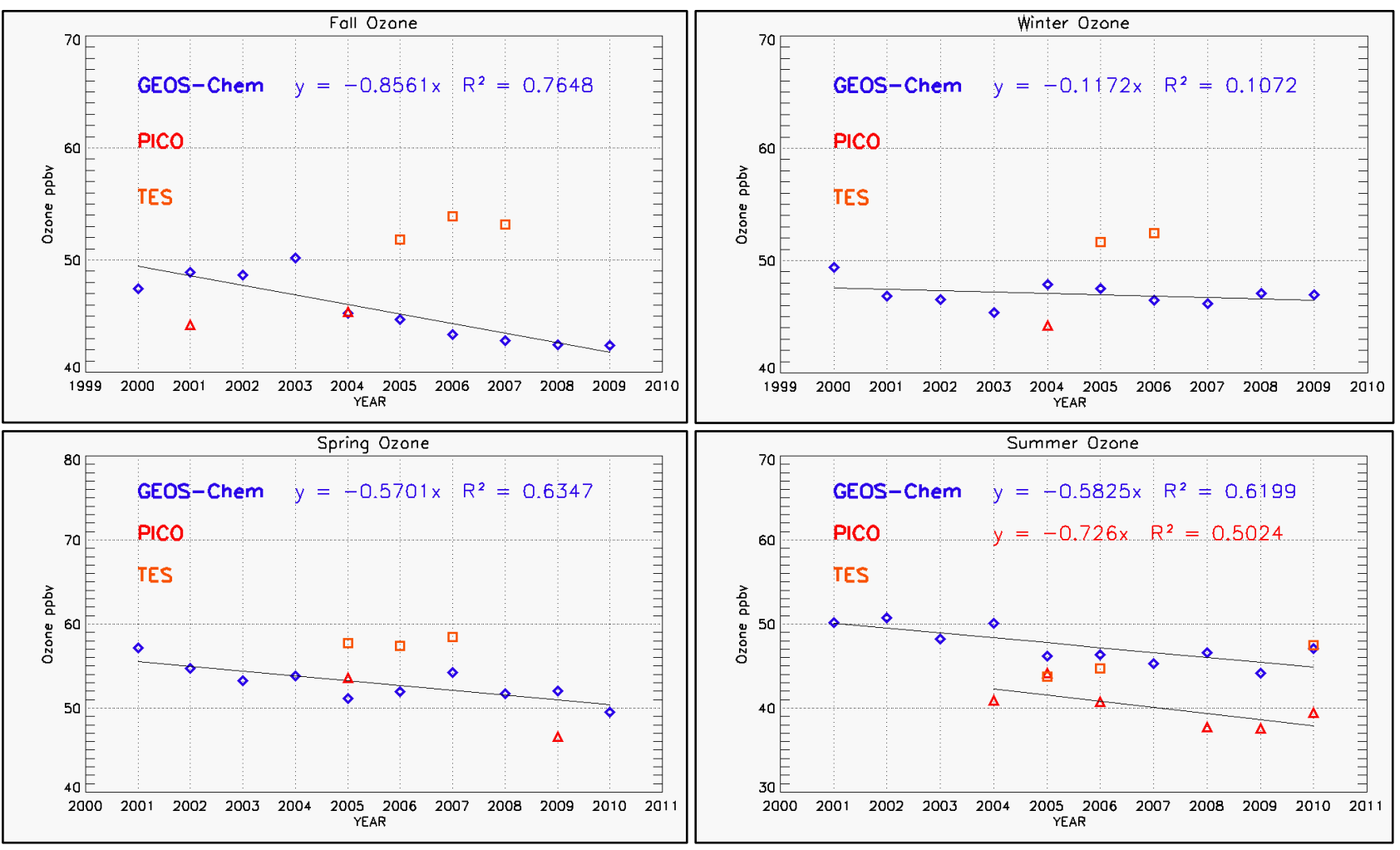

Figure 10: Seasonal modeled trends for $\mathrm{O}_{3}$ at Pico station. GEOS-Chem shows declines in all seasons. 
Based on model results, significant declines in fall $\mathrm{CO}$ of $\sim 0.798$ ppbv/year have occurred over the study period. This matches closely with AIRS, which shows a decline of $\sim 0.837 \mathrm{ppbv} / \mathrm{year}$ in the fall. GEOS-Chem shows CO declines in other seasons of $\sim 0.35 \mathrm{ppbv} / \mathrm{year}$, while AIRS indicates declines of $\sim 0.5 \mathrm{ppbv} / \mathrm{year}$. Pico CO data shows a large decline in the summer record of $\sim 1.3$ ppbv/year; this is most likely due to the shorter record and high CO levels in the summer of 2003 which was a particularly high biomass burning year.

Model results for $\mathrm{O}_{3}$ show a fall decline of $\sim 0.85 \mathrm{ppbv} / \mathrm{year}$ and declines in summer and spring of $\sim 0.58$ ppbv/year. Pico $\mathrm{O}_{3}$ data also shows a declining $\mathrm{O}_{3}$ level in the summer period of $\sim 0.73$ ppbv/year. Model results for winter $\mathrm{O}_{3}$ show a decline of $\sim 0.117$ which is essentially a flat trend. Table 6 shows model trend results for both CO and $\mathrm{O}_{3}$.

Table 6: Model trend results for $\mathrm{CO}$ and $\mathrm{O}_{3}$ (ppbv/year) on a seasonal basis.

\begin{tabular}{|c|c|c|}
\hline & CO & $\mathbf{O}_{\mathbf{3}}$ \\
\hline Fall (2000 - 2009) & -0.798 & -0.856 \\
\hline Winter (2000 - 2009) & -0.393 & -0.117 \\
\hline Spring (2001 - 2010) & -0.307 & -0.570 \\
\hline Summer (2001- 2010) & -0.368 & -0.583 \\
\hline
\end{tabular}

\section{(5.2) No North American Fossil Fuel Emissions}

Model sensitivity to North American (NA) fossil fuel emissions indicate that the average NA contribution to $\mathrm{CO}$ and $\mathrm{O}_{3}$ at Pico is 8.57 and 4.03 ppbv respectively based on monthly averages. Table 7 shows the contribution for seasonal NA contributions. For $\mathrm{CO}$ the largest difference is seen in winter and spring. This is likely due to the higher contribution of biogenic and biomass burning during the summer and fall. Thus, NA 
fossil fuel emissions are less of the total $\mathrm{CO}$ reaching Pico in those seasons. Ozone shows similar decreases in all seasons except for winter. In winter there is less of an impact from NA fossil fuel emissions, this may be due to longer chemical lifetimes in the winter and hence an increase in the influence of Asian emissions during winter.

Table 7: GEOS-Chem North American fossil fuel emissions contribution to concentrations of $\mathrm{CO}$ and $\mathrm{O}_{3}$ at Pico station from the fall of 2000 through the summer of 2010.

\begin{tabular}{|c|c|c|}
\hline & CO (ppbv) & $\mathbf{O}_{\mathbf{3}}(\mathbf{p p b v})$ \\
\hline Fall & 5.71 & 4.44 \\
\hline Winter & 12.68 & 2.29 \\
\hline Spring & 11.01 & 4.45 \\
\hline Summer & 4.90 & 4.94 \\
\hline Annual & $\mathbf{8 . 5 7}$ & $\mathbf{4 . 0 3}$ \\
\hline
\end{tabular}

The impact of no NA fossil fuel emissions on modeled trends are shown in Figures 11 and 12. For $\mathrm{CO}$ the greatest difference in trend results is seen in the fall, with a decrease of $0.5671 \mathrm{ppbv} / \mathrm{year}$ in the magnitude of the declining trend. Winter shows less of an impact from shutting off NA fossil fuel emissions. This could be due to longer chemical lifetimes increasing the influence of Asian emissions in these seasons. For spring there is essentially no change. This may be due to a combination of longer lifetimes in early spring and increased impact of biomass burning and biogenic emissions in late spring. The summer CO modeled trend actually increased slightly, 0.0569 ppbv/year. One possible explanation is that there was a larger decline in Northern Hemisphere $(\mathrm{NH})$ biomass burning than there was in NA CO emissions. Based on data 
in table 3, there was a $5.24 \mathrm{ppbv/year}$ decrease in $\mathrm{NH}$ biomass burning compared to a $2.33 \mathrm{ppbv/year} \mathrm{decrease} \mathrm{in} \mathrm{NA} \mathrm{CO} \mathrm{emissions.}$

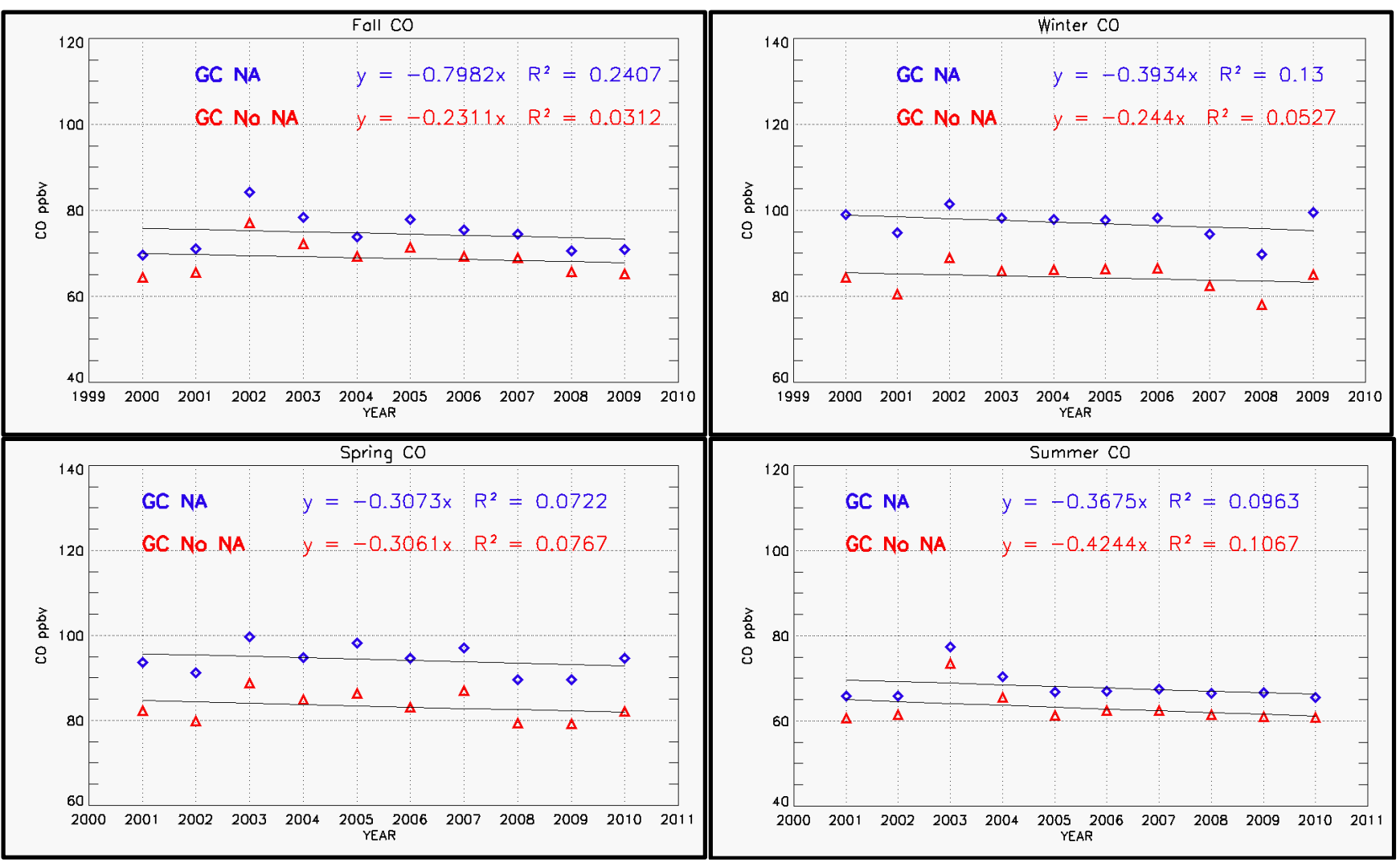

Figure 11: Model trends for CO with (blue) and without (red) North American fossil fuel emissions.

For $\mathrm{O}_{3}$ there are similar changes in all seasons. The declining model trend decreases in spring through fall by roughly $0.4 \mathrm{ppbv/year.} \mathrm{The} \mathrm{impact} \mathrm{of} \mathrm{no} \mathrm{NA} \mathrm{fossil} \mathrm{fuel} \mathrm{emissions} \mathrm{is} \mathrm{less} \mathrm{in} \mathrm{winter;} \mathrm{there}$ was a $0.2 \mathrm{ppbv} / \mathrm{year}$ change in the winter trend. Winter $\mathrm{O}_{3}$ modeled trends without NA fossil fuel emissions goes from being slightly negative to slightly positive. Again this is likely due to longer chemical lifetimes of $\mathrm{O}_{3}$ precursors during the winter season increasing the influence of rising Asian emissions. Table 8 lists model trends for $\mathrm{CO}$ and $\mathrm{O}_{3}$ with and without $\mathrm{NA}$ fossil fuel emissions. 


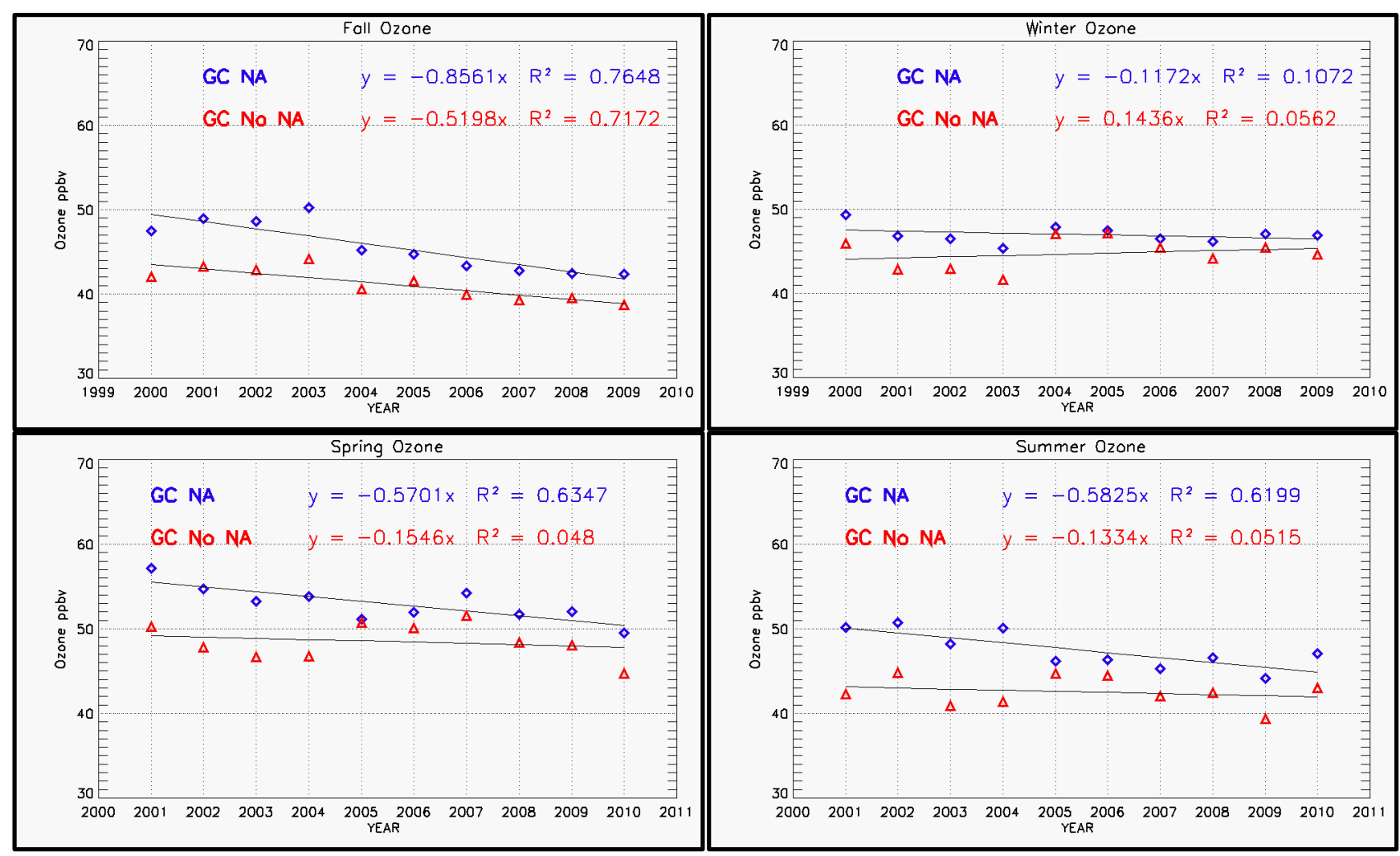

Figure 12: Model trends for $\mathrm{O}_{3}$ with and without NA fossil fuel emissions.

Table 8: Model trend results for $\mathrm{CO}$ and $\mathrm{O}_{3}$ (ppbv/year) with (w/NA) and without (no NA) North American fossil fuel emissions.

\begin{tabular}{|l|l|l|l|l|}
\hline & \multicolumn{2}{|c|}{ CO } & \multicolumn{2}{c|}{ O $_{3}$} \\
\hline & No NA & w/NA & No NA & w/NA \\
\hline Fall & -0.231 & -0.798 & -0.520 & -0.856 \\
\hline Winter & -0.244 & -0.393 & +0.144 & -0.117 \\
\hline Spring & -0.306 & -0.307 & -0.155 & -0.570 \\
\hline Sumer & -0.424 & -0.368 & -0.133 & -0.583 \\
\hline
\end{tabular}

\section{(6) Discussion}

\section{(6.1) GEOS-Chem vs. Satellite and Pico Data}

For the summer period of 2004 used to generate Figure 6, model CO is on average $27.0+/-8.62(1-\sigma)$ ppbv low, while AIRS is $12.7+/-4.67$ ppbv higher than Pico data; these are in agreement with other findings in the literature where model $\mathrm{CO}$ is 10 to 25 
ppbv low [Bey et al., 2001; Kopacz et al., 2010]. Compared to AIRS, GEOS-Chem is $39.6+/-4.50$ ppbv CO lower for the summer 2004 period. Winter shows the least discrepancy between model and AIRS data with GEOS-Chem being 14.07 +/-8.61 ppbv CO lower than AIRS. Table 9 shows the monthly differences between the various data sets used for the full year record in Figure 6. The average seasonal difference for 2004 through 2005 and full record differences are provided in Table 10. For all seasons GEOS-Chem is $13.10+/-24.21$ ppbv low compared to Pico and $28.98+/-9.91$ low compared to AIRS. The full record results show that AIRS is $1.89+/-10.58$ ppbv high compared to the Pico data. GEOS-Chem CO is likely low compared to Pico and AIRS due to high model $\mathrm{OH}$ and underestimates in emissions, particularly biogenic emissions [Bey et al., 2001].

Table 9: Difference between monthly average CO (ppbv) based on 24 hour averages for the period from SEP 04 to AUG 05. Red values indicate maximum differences and blue values represent minimum differences.

\begin{tabular}{|c|c|c|c|}
\hline & GEOS-Chem - Pico & GEOS-Chem - AIRS & AIRS - Pico \\
\hline JAN & -21.1 & -9.01 & -12.1 \\
\hline FEB & -20.95 & -9.18 & -11.8 \\
\hline MAR & -21.0 & -4.39 & -16.9 \\
\hline APR & -36.1 & -24.3 & -11.9 \\
\hline MAY & -46.2 & -45.0 & -1.28 \\
\hline JUN & -33.6 & -43.8 & +7.22 \\
\hline JUL & -24.4 & -40.0 & +15.6 \\
\hline AUG & -20.0 & -34.9 & +14.8 \\
\hline SEP & -27.0 & -39.7 & +12.8 \\
\hline OCT & -20.1 & -35.3 & +15.2 \\
\hline NOV & -18.9 & -30.5 & +11.5 \\
\hline DEC & -18.0 & -24.0 & +6.06 \\
\hline AVG & $\mathbf{- 2 5 . 9}$ & $\mathbf{- 2 8 . 3}$ & $\mathbf{+ 2 . 4 6}$ \\
\hline SD & $\mathbf{8 . 9 8}$ & $\mathbf{1 4 . 2}$ & $\mathbf{1 2 . 5}$ \\
\hline
\end{tabular}


Table 10: Average seasonal differences and standard deviation $(1 \sigma)$ for the 2004 to 2005 time period used in Figure 6 . The far right lists the average differences for all available data from the fall of 2000 thru August 2010.

\begin{tabular}{|l|l|l|l|l|l|}
\hline CO & Fall & Winter & Spring & Summer & $\begin{array}{l}\text { Full } \\
\text { Record }\end{array}$ \\
\hline $\begin{array}{l}\text { GEOS-Chem - } \\
\text { Pico }\end{array}$ & $\begin{array}{l}-22.5 \\
+/-4.06\end{array}$ & $\begin{array}{l}-20.0 \\
+/-1.81\end{array}$ & $\begin{array}{l}-34.4 \\
+/-12.68\end{array}$ & $\begin{array}{l}-27.0 \\
+/-8.62\end{array}$ & $\begin{array}{l}-13.10 \\
+/-24.21\end{array}$ \\
\hline AIRS - Pico & +12.7 & -5.95 & $\begin{array}{l}-9.89 \\
+/-10.42\end{array}$ & $\begin{array}{l}+1-7.86 \\
+/-4.67\end{array}$ & $\begin{array}{l}+1.89 \\
+/-10.58\end{array}$ \\
\hline $\begin{array}{l}\text { GEOS-Chem - } \\
\text { AIRS }\end{array}$ & $\begin{array}{l}-35.1 \\
+/-4.59\end{array}$ & $\begin{array}{l}-14.07 \\
+/-8.61\end{array}$ & $\begin{array}{l}-24.5 \\
+/-20.27\end{array}$ & $\begin{array}{l}-39.6 \\
+/-4.50\end{array}$ & $\begin{array}{l}-28.98 \\
+/-9.91\end{array}$ \\
\hline
\end{tabular}

Ozone is somewhat more difficult to analyze given the lack of TES data and only six years of complete summer record at Pico. Over the summer period of 2004, GEOSChem was found to be $+5.69+/-4.00$ ppbv higher than Pico data and $+3.13+/-3.53$ ppbv higher than TES $(n=3)$, this is also within the $+/-10$ ppbv model $\mathrm{O}_{3}$ range reported by Bey et al (2001). TES was +3.73 +/- 1.27 ppbv compared to summer 2004 Pico measurements. Table 11 shows values for differences of the full year record analyzed in this study. Table 12 provides the average seasonal differences for the 2004 to 2005 record used to generate Figure 6 as well as the average difference based on all available data. For the full record available GEOS-Chem ozone averaged $+3.53+/-2.27 \mathrm{ppbv}$ compared to Pico data; TES averaged +4.02 +/-0.15 ppbv. GEOS-Chem averaged -4.98 +/-3.79 ppbv lower than TES. 
Table 11: Monthly ozone differences based on hourly averages for the period covering SEP 04 to AUG 05 using the same data used in Figure 6. Values are ppbv. Red values indicate maximum differences and blue values represent minimum differences.

\begin{tabular}{|c|c|c|c|}
\hline & GEOS-Chem - Pico & GEOS-Chem - TES & TES - Pico \\
\hline JAN & 5.84 & -3.98 & 9.82 \\
\hline FEB & 4.74 & -3.97 & 8.71 \\
\hline MAR & 4.08 & -2.72 & 6.80 \\
\hline APR & 8.13 & -9.10 & 8.2 \\
\hline MAY & 5.23 & -2.90 & \\
\hline JUN & 3.25 & & 4.63 \\
\hline JUL & 10.3 & 5.67 & 2.83 \\
\hline AUG & 3.51 & 0.675 & \\
\hline SEP & 3.05 & & \\
\hline OCT & 3.66 & & $\mathbf{8 . 3 1}$ \\
\hline NOV & 4.74 & & $\mathbf{4 . 6 2}$ \\
\hline DEC & 3.77 & $\mathbf{- 2 . 3 3}$ & \\
\hline AVG & $\mathbf{5 . 0 2}$ & $\mathbf{4 . 5 6}$ & \\
\hline SD & $\mathbf{2 . 1 8}$ & &
\end{tabular}

Table 12: Average seasonal differences and standard deviation $(1 \sigma)$ for the 2004 to 2005 time period used in Figure 6. The far right lists the average differences for all available data from the fall of 2000 thru August 2010.

\begin{tabular}{|c|c|c|c|c|c|}
\hline Ozone (ppbv) & Fall & Winter & Spring & Summer & $\begin{array}{l}\text { Full } \\
\text { Record }\end{array}$ \\
\hline $\begin{array}{l}\text { GEOS-Chem - } \\
\text { Pico }\end{array}$ & $\begin{array}{l}+3.81 \\
+/- \\
0.855\end{array}$ & $\begin{array}{l}+4.78 \\
+/-1.03\end{array}$ & $\begin{array}{l}+5.81 \\
+/-2.09\end{array}$ & $\begin{array}{l}+5.69 \\
+/-4.00\end{array}$ & $\begin{array}{l}+3.53 \\
+/-2.27\end{array}$ \\
\hline TES - Pico & $\begin{array}{l}+9.14 \\
+/-6.05\end{array}$ & $\begin{array}{l}+8.58 \\
+/-1.04\end{array}$ & $\begin{array}{l}+10.7 \\
+/-5.68\end{array}$ & $\begin{array}{l}+3.73 \\
+/-1.27\end{array}$ & $\begin{array}{l}+4.02 \\
+/-0.15\end{array}$ \\
\hline $\begin{array}{l}\text { GEOS-Chem - } \\
\text { TES }\end{array}$ & $\begin{array}{l}-5.33 \\
+/-5.36\end{array}$ & $\begin{array}{l}-3.79 \\
+/-0.31\end{array}$ & $\begin{array}{l}-4.91 \\
+/-3.63\end{array}$ & $\begin{array}{l}+3.17 \\
+/-3.53\end{array}$ & $\begin{array}{l}-4.98 \\
+/-3.79\end{array}$ \\
\hline
\end{tabular}

Large discrepancies between GEOS-Chem and AIRS have been noted, particularly for the summer and fall seasons; with GEOS-Chem being lower than AIRS by $-40.1+/-2.72 \mathrm{ppbv}$ and $-33.2+/-2.57 \mathrm{ppbv}(1 \sigma)$ respectively. GEOS-Chem was closer to TES for $\mathrm{O}_{3}$ with fall showing the largest discrepancy; the model was $-9.37+/-$ 1.94 ppbv lower than TES $(1 \sigma)$. Spring and winter showed the next largest GEOS-Chem vs. TES discrepancies; the model was $\sim-5+/-1$ ppbv low. For summer ozone, GEOS- 
Chem and TES were within $1.2+/-1.47 \mathrm{ppbv}$ with the model again being low. Based on the satellite averaging kernels they are most sensitive in the 300 to $400 \mathrm{hPa}$ levels [Jin, 2011]. Thus, although any 'trends' indicated by them will be valid, the absolute values at the lower troposphere levels we are looking at will not be nearly as accurate. This also explains why there is such little variation in the AIRS CO data. It is therefore, not accurate to compare the magnitude of differences between model and Pico data results to the satellites without first applying the averaging kernel to the model and data.

\section{(6.2) Trends}

It was intended to compare GEOS-Chem results to Pico data trend results; insufficient Pico data prevents us from using it for trend analysis. The average annual model decline for $\mathrm{CO}$ and $\mathrm{O}_{3}$ with $\mathrm{NA}$ fossil fuel emissions is 0.467 ppbv/year and $0.531 \mathrm{ppbv} / \mathrm{year}$ respectively. We have shown that the model, Pico data, and satellite retrievals all display the characteristic seasonal cycles for both $\mathrm{CO}$ and $\mathrm{O}_{3}$; although a full year record overlap for Pico data and TES was not available. We have also shown that GEOS-Chem and Pico data appear to agree well in terms of seasonal variation over the long term record and within expectations based on previous GEOS-Chem results. For periods of available overlapping data, all datasets show the same direction of declining trends, but different magnitudes. Given the availability of Pico data our highest confidence is in the summer months. With 8 years of $\mathrm{CO}$ coverage provided by AIRS we can also be relatively confident in $\mathrm{CO}$ results for other seasons. Given the limited availability of $\mathrm{O}_{3}$ coverage for periods outside the summer season it is more difficult to 
definitively declare any trends in $\mathrm{O}_{3}$ for fall thru spring; although available Pico data in those seasons matches well with GEOS-Chem output.

\section{(6.3) North American Emissions}

Based on the EPA data from Figure 1 there was a $32.1 \%$ reduction in U.S. CO emissions from 2000 to 2008 . Highway vehicles are the largest source of CO in the U.S.; this category also contributed to a majority of the reductions. Table A3 in the appendix shows U.S. emission changes based on source category. Over our study period the model shows an average decline of $14.27 \%$ for NA CO. The discrepancy may be due to either GEOS-Chem scale factors being too low or the fact that we analyzed all of North America, not just the U.S. Mexican emissions are not as well quantified as U.S. and Canadian emissions thus it is difficult to obtain accurate emission trends from this part of NA.

Based on model results without NA fossil fuel emissions, CO declined on average for all seasons by $0.301 \mathrm{ppbv} / \mathrm{year}$ and $\mathrm{O}_{3}$ declined by 0.166 . This represents a $35.5 \%$ reduction in the magnitude of decline for $\mathrm{CO}$ and a $68.7 \%$ reduction in the magnitude of decline for $\mathrm{O}_{3}$. Ozone may have declined by larger amounts due to U.S. emission decreases in NOx and VOCs.

\section{(7) Conclusion}

Ten years of GEOS-Chem simulated $\mathrm{CO}$ and $\mathrm{O}_{3}$ reveal that GEOS-Chem captures the annual and long term trends reasonably well and within the expected range of accuracy $\left(+10\right.$ to +50 ppbv $\left.\mathrm{CO},+/-10 \mathrm{ppbv} \mathrm{O}_{3}\right)$ based on other studies. For $\mathrm{CO}$ the 
model is consistently low, particularly during the spring. Simulated ozone matches insitu measurements very well throughout the year. Using GEOS-4 and GEOS-5 does not appear to greatly impact model results for the study location.

Given the availability of Pico data and satellite retrievals our highest confidence is in summer $\mathrm{CO}$ and $\mathrm{O}_{3}$. The 10 year simulation shows declining $\mathrm{CO}$ and $\mathrm{O}_{3}$ over the period from 2001 to 2010. All three data sets show a downward trend in CO during summer. The more limited coverage of Pico and TES $\mathrm{O}_{3}$ data limits our ability to corroborate the downward summer $\mathrm{O}_{3}$ trend; however, both model and in-situ measurements indicate a decline.

Eight years of AIRS CO data shows agreement with the modeled decline in all seasons. Large discrepancies between GEOS-Chem and AIRS are likely the result of AIRS lower sensitivity at such low altitudes and our lack of applying the AIRS averaging kernel to model results. This does not limit AIRS usefulness in corroborating the direction of declining $\mathrm{CO}$ levels.

Model results for ozone show declines in all seasons with winter being essentially flat. The Pico data agrees with model results of declining $\mathrm{O}_{3}$ in summer but has a much shorter record. The limited TES data does not allow for adequate comparison. This highlights the value of models for analyzing trends.

Model results for both $\mathrm{CO}$ and $\mathrm{O}_{3}$ show the largest declines in fall. Carbon monoxide shows similar declines in other seasons; however the magnitude is considerably less. Ozone for spring and summer show similar declines while winter shows essentially no change over the ten year period. Thus we tentatively conclude that declines in North American emissions of $\mathrm{O}_{3}$ precursors have resulted in declining $\mathrm{O}_{3}$ over 
the North Atlantic lower free troposphere. The winter $\mathrm{O}_{3}$ results may be due to longer photochemical lifetimes of $\mathrm{O}_{3}$ and its precursors increasing the influence of rising Asian emissions.

Sensitivity studies with GEOS-Chem show that North American (NA) fossil fuel emissions contribute $8.57 \mathrm{ppbv} \mathrm{CO} / \mathrm{year}$ and $4.03 \mathrm{ppbv} \mathrm{O}_{3} /$ year to Pico station. The magnitude of the change in $\mathrm{CO}$ trends of $35.5 \%$ compares well to the EPA reported 32.1\% U.S. emission reduction. Turning off NA fossil fuel emissions decreases model trends in all seasons for all species except summer CO. We postulate that the increasing decline in summer $\mathrm{CO}$ at Pico without NA fossil fuel emissions is the result of a larger decreasing trend in Northern Hemisphere biomass burning compared to the NA anthropogenic $\mathrm{CO}$ decline over the period studied. Only the model winter $\mathrm{O}_{3}$ trend went from being negative to positive. The change in winter $\mathrm{O}_{3}$ with and without NA emissions was approximately half of that seen in other seasons. The lower influence of NA anthropogenic emissions in winter is likely due to longer chemical lifetimes; thus, Asian emissions of $\mathrm{O}_{3}$ precursors have more of an influence in winter compared to other seasons, and less of a change between the two emission scenarios is observed with GEOS-Chem.

\section{(8) Future Works}

\section{Data Processing}

A more accurate method of comparing GEOS-Chem to the data would be to select only Pico days with 24 hour coverage and compare only the corresponding days to the 
model and satellite output. By our inclusion of days with less than complete coverage we may be exacerbating the differences between model output and Pico data. For example, if only 10 data points are available and those points occur during a fire event, the data would be considerably higher than the model for that time period. The Pico data could also be processed to exclude fire events. As we have shown, the model does not handle transport of fire plumes well over long distances. By including these events in the Pico data, we may be adding to the discrepancy between the model and the data. Also, including biomass burning in the model will influence model background concentrations of $\mathrm{CO}$ and $\mathrm{O}_{3}$ over Pico thus possibly influencing the modeled trends. Excluding biomass burning in the model and the data would allow one to better isolate the impact of changing anthropogenic emissions on $\mathrm{CO}$ and $\mathrm{O}_{3}$ trends at Pico.

Another method to compare GEOS-Chem with the satellite data would be to apply the averaging kernel to GEOS-Chem. At the same time, it may be useful to only compare data points at times corresponding to the satellite crossing time of 01:45 and 13:45. The MOPIT (Measurements of Pollution in the Troposphere) satellite would also be a useful tool for evaluating $\mathrm{CO}$ trends. MOPIT has the advantage of having coverage over the entire study period and has well documented comparisons to GEOS-Chem.

\section{Modeling}

One feature of GEOS-Chem which could be particularly useful in better quantifying the impact of specific emission regions on the North Atlantic lower free troposphere is a tagged $\mathrm{CO}$ simulation. The tagged $\mathrm{CO}$ simulation only calculates $\mathrm{CO}$ concentration using archived $\mathrm{OH}$ concentrations from a previous run. This type of 
simulation places a source tag on CO which identifies the tracer's source region. Sources are divided amongst North American, European, Asian, and other. In addition, $\mathrm{CO}$ is tagged from biomass burning per region, global $\mathrm{CH}_{4}$, global biofuel, global monterpene, global isoprene, and global acetone Thus, one can easily quantify the relative source attribution for any particular region of interest. 


\section{Acknowledgements}

The author would like to thank his advisory committee for their help, encouragement, and instruction along the way. Special thanks are also owed to Bob Page and Mackenzie Roeser for their help with GEOS-Chem and IDL. We would like to recognize the contribution of Richard Honrath, without whom, Pico station would not exist. Similarly, thank you to Michael Dizobak, Detlev Helmig, and Paulo Fialho for their contributions on the PICO-NARE project. We would also like to thank the members of the MTU GEOS-Chem users group for their encouragement and help, including: Yaoxian Huang, Huanxin Zhang, and Wenchao Chen. Lastly but certainly not least, I would like to thank my family and wife, Mary Weise, for their support and encouragement, and for putting up with me along the way. 


\section{References}

Acker, J. G., and G. Leptoukh (2007), Online Analysis Enhances Use of NASA Earth Science Data, in Eos, edited, pp. 14-17, Trans. AGU.

Bey, I., D. J. Jacob, R. M. Yantosca, J. A. Logan, B. D. Field, A. M. Fiore, Q. B. Li, H. G. Y. Liu, L. J. Mickley, and M. G. Schultz (2001), Global modeling of tropospheric chemistry with assimilated meteorology: Model description and evaluation, J Geophys Res-Atmos, 106(D19), 23073-23095.

Canada, E. (2005), National Pollutant Release Inventory, edited.

Choi, Y., Y. Wang, T. Zeng, D. Cunnold, E. S. Yang, R. Martin, K. Chance, V. Thouret, and E. Edgerton (2008), Springtime transitions of NO2, CO, and O-3 over North America: Model evaluation and analysis, J Geophys Res-Atmos, 113(D20).

Duncan, B. N., and J. A. Logan (2008), Model analysis of the factors regulating the trends and variability of carbon monoxide between 1988 and 1997, Atmospheric Chemistry and Physics, 8(24), 7389-7403.

Duncan, B. N., J. A. Logan, I. Bey, I. A. Megretskaia, R. M. Yantosca, P. C. Novelli, N. B. Jones, and C. P. Rinsland (2007), Global budget of CO, 1988-1997: Source estimates and validation with a global model, J Geophys Res-Atmos, 112(D22).

EPA, U. (2005), 2005 National Emissions Inventory Data \& Documentation, edited. EPA, U. (2011), Ozone Pollution, edited by U. E. P. Agency.

Fisher, J. A., et al. (2010), Source attribution and interannual variability of Arctic pollution in spring constrained by aircraft (ARCTAS, ARCPAC) and satellite (AIRS) observations of carbon monoxide, Atmospheric Chemistry and Physics, 10(3), 977-996. 
Fusco, A. C., and J. A. Logan (2003), Analysis of 1970-1995 trends in tropospheric ozone at Northern Hemisphere midlatitudes with the GEOS-CHEM model, J Geophys Res-Atmos, 108(D15).

Guenther, A., T. Karl, P. Harley, C. Wiedinmyer, P. I. Palmer, and C. Geron (2006), Estimates of global terrestrial isoprene emissions using MEGAN (Model of Emissions of Gases and Aerosols from Nature), Atmospheric Chemistry and Physics, 6, 3181-3210.

Helmig, D., D. M. Tanner, R. E. Honrath, R. C. Owen, and D. D. Parrish (2008), Nonmethane hydrocarbons at Pico Mountain, Azores: 1. Oxidation chemistry in the North Atlantic region, $J$ Geophys Res-Atmos, 113(D20).

Holloway, T., H. Levy, and P. Kasibhatla (2000), Global distribution of carbon monoxide, $J$ Geophys Res-Atmos, 105(D10), 12123-12147.

Honrath, R., R. C. Owen, M. Val Martin, J. Reid, K. Lapina, M. Fialho, M. P. Dziobak, J. Kleissl, and D. Westphal (2004), Regional and hemispheric impacts of antrhopogenic and biomass burning emissions on summertime $\mathrm{CO}$ and $\mathrm{O} 3$ in the North Atlantic lower free troposphere, Journal of Geophysical Research, 109.

Honrath, R. E., D. Helmig, R. C. Owen, D. D. Parrish, and D. M. Tanner (2008), Nonmethane hydrocarbons at Pico Mountain, Azores: 2. Event-specific analyses of the impacts of mixing and photochemistry on hydrocarbon ratios, J Geophys Res-Atmos, 113(D20).

Hudman, R. C., L. T. Murray, D. J. Jacob, S. Turquety, S. Wu, D. B. Millet, M. Avery, A. H. Goldstein, and J. Holloway (2009), North American influence on tropospheric ozone and the effects of recent emission reductions: Constraints from ICARTT observations, J Geophys ResAtmos, 114, -. 
Hudman, R. C., L. T. Murray, D. J. Jacob, D. B. Millet, S. Turquety, S. Wu, D. R. Blake, A. H. Goldstein, J. Holloway, and G. W. Sachse (2008), Biogenic versus anthropogenic sources of CO in the United States, Geophys. Res. Lett., 35(4).

Jacob, D. J. (1999), Introduction to atmospheric chemistry, xii, 266 p. pp., Princeton University Press, Princeton, N.J.

Jacobson, M. Z., and R. P. Turco (1994), Smvgear - a Sparse-Matrix, Vectorized Gear Code for Atmospheric Models, Atmospheric Environment, 28(2), 273-284.

Jin, J. (2011), Personal Communication, edited by JPL/Caltech.

Khalil, M. A. K., and R. A. Rasmussen (1990), THE GLOBAL CYCLE OF CARBONMONOXIDE - TRENDS AND MASS BALANCE, Chemosphere, 20(1-2), 227-242.

Kleissl, J., R. E. Honrath, M. P. Dziobak, D. Tanner, M. V. Martin, R. C. Owen, and D. Helmig (2007), Occurrence of upslope flows at the Pico mountaintop observatory: A case study of orographic flows on a small, volcanic island, J Geophys Res-Atmos, 112(D10).

Kopacz, M., et al. (2010), Global estimates of CO sources with high resolution by adjoint inversion of multiple satellite datasets (MOPITT, AIRS, SCIAMACHY, TES), Atmospheric Chemistry and Physics, 10(3), 855-876.

Kuhns, H., E. M. Knipping, and J. M. Vukovich (2005), Development of a United States-Mexico emissions inventory for the Big Bend Regional Aerosol and Visibility Observational (BRAVO) Study, Journal of the Air \& Waste Management Association, 55(5), 677-692.

Lapina, K., R. E. Honrath, R. C. Owen, M. V. Martin, and G. Pfister (2006), Evidence of significant large-scale impacts of boreal fires on ozone levels in the midlatitude Northern Hemisphere free troposphere, Geophys. Res. Lett., 33(10), 4. 
Li, Q. B., et al. (2002), Transatlantic transport of pollution and its effects on surface ozone in Europe and North America, J Geophys Res-Atmos, 107(D13).

Martin, M. V., R. E. Honrath, R. C. Owen, G. Pfister, P. Fialho, and F. Barata (2006), Significant enhancements of nitrogen oxides, black carbon, and ozone in the North Atlantic lower free troposphere resulting from North American boreal wildfires, J Geophys Res-Atmos, 111(D23).

McLinden, C. A., S. C. Olsen, B. Hannegan, O. Wild, M. J. Prather, and J. Sundet (2000), Stratospheric ozone in 3-D models: A simple chemistry and the cross-tropopause flux, J Geophys Res-Atmos, 105(D11), 14653-14665.

McMillan, W. W., C. Barnet, L. Strow, M. T. Chahine, M. L. McCourt, J. X. Warner, P. C. Novelli, S. Korontzi, E. S. Maddy, and S. Datta (2005), Daily global maps of carbon monoxide from NASA's Atmospheric Infrared Sounder, Geophys. Res. Lett., 32(11).

Moorthi, S., and M. J. Suarez (1992), Relaxed Arakawa-Schubert - a Parameterization of Moist Convection for General-Circulation Models, Mon Weather Rev, 120(6), 978-1002.

Olivier, J. G. J., and J. J. M. Berdowski (Eds.) (2001), Global emissions sources and sinks 33-78 pp., A. A. Balkema Publishers/Swets \& Zeitlinger Publishers, Lisse, The Netherlands.

Owen, R. C., O. R. Cooper, A. Stohl, and R. E. Honrath (2006), An analysis of the mechanisms of North American pollutant transport to the central North Atlantic lower free troposphere, $J$ Geophys Res-Atmos, 111(D23), 14.

Pfister, G. G., et al. (2006), Ozone production from the 2004 North American boreal fires, $J$ Geophys Res-Atmos, 111(D24).

Rastigejev, Y., R. Park, M. P. Brenner, and D. J. Jacob (2010), Resolving intercontinental pollution plumes in global models of atmospheric transport, J Geophys Res-Atmos, 115, -. 
Sakulyanontvittaya, T., T. Duhl, C. Wiedinmyer, D. Helmig, S. Matsunaga, M. Potosnak, J. Milford, and A. Guenther (2008), Monoterpene and sesquiterpene emission estimates for the United States, Environmental Science \& Technology, 42(5), 1623-1629.

Seinfeld, J. H., and S. N. Pandis (2006), Atmospheric chemistry and physics : from air pollution to climate change, 2nd ed., xxviii, 1203 p. pp., J. Wiley, Hoboken, N.J.

Streets, D. G., et al. (2003), An inventory of gaseous and primary aerosol emissions in Asia in the year 2000, J Geophys Res-Atmos, 108(D21).

van der Werf, G. R., J. T. Randerson, L. Giglio, G. J. Collatz, P. S. Kasibhatla, and A. F. Arellano (2006), Interannual variability in global biomass burning emissions from 1997 to 2004, Atmospheric Chemistry and Physics, 6, 3423-3441.

van Donkelaar, A., et al. (2008), Analysis of aircraft and satellite measurements from the Intercontinental Chemical Transport Experiment (INTEX-B) to quantify long-range transport of East Asian sulfur to Canada, Atmospheric Chemistry and Physics, 8(11), 2999-3014.

Vestreng, V., and H. Klein (2002), Emission data reported to UNECE/EMEP: Wuality insurance and trend analysis and presentation of Web-Dab., edited by N. M. Institute, Oslo, Norway. Vingarzan, R. (2004), A review of surface ozone background levels and trends, Atmospheric Environment, 38(21), 3431-3442.

Wang, H. Q., D. J. Jacob, P. Le Sager, D. G. Streets, R. J. Park, A. B. Gilliland, and A. van Donkelaar (2009), Surface ozone background in the United States: Canadian and Mexican pollution influences, Atmospheric Environment, 43(6), 1310-1319.

Yevich, R., and J. A. Logan (2003), An assessment of biofuel use and burning of agricultural waste in the developing world, Global Biogeochemical Cycles, 17(4). 
Yurganov, L. N., W. W. McMillan, A. V. Dzhola, E. I. Grechko, N. B. Jones, and G. R. van der Werf (2008), Global AIRS and MOPITT CO measurements: Validation, comparison, and links to biomass burning variations and carbon cycle, J Geophys Res-Atmos, 113(D9), 14.

Zhang, G. J., and N. A. Mcfarlane (1995), Sensitivity of Climate Simulations to the Parameterization of Cumulus Convection in the Canadian Climate Center General-Circulation Model, Atmos Ocean, 33(3), 407-446.

Zhang, L., D. J. Jacob, X. Liu, J. A. Logan, K. Chance, A. Eldering, and B. R. Bojkov (2010), Intercomparison methods for satellite measurements of atmospheric composition: application to tropospheric ozone from TES and OMI, Atmospheric Chemistry and Physics, 10(10), 4725-4739. Zhang, L., et al. (2006), Ozone-CO correlations determined by the TES satellite instrument in continental outflow regions, Geophys. Res. Lett., 33(18), -. Zhang, L., et al. (2008), Transpacific transport of ozone pollution and the effect of recent Asian emission increases on air quality in North America: an integrated analysis using satellite, aircraft, ozonesonde, and surface observations, Atmospheric Chemistry and Physics, 8(20), 6117-6136. 


\section{Appendix:}

Table A1: Significant reactions and rates for the chemical species in this study. Adapted from http://acmg.seas.harvard.edu/geos/wiki_docs/chemistry/geoschem_mech.pdf

\begin{tabular}{|l|l|l|}
\hline Reaction & Rate & Source \\
\hline $\mathrm{O} 3+\mathrm{NO}=\mathrm{NO} 2+\mathrm{O} 2$ & $3.00 \mathrm{E}-12 \exp (-1500 / \mathrm{T})$ & JPL00 \\
\hline $\mathrm{O} 3+\mathrm{OH}=\mathrm{HO} 2+\mathrm{O} 2$ & $1.70 \mathrm{E}-12 \exp (-940 / \mathrm{T})$ & JPL02 \\
\hline $\mathrm{O} 3+\mathrm{HO} 2=\mathrm{OH}+2 \mathrm{O} 2$ & $1.00 \mathrm{E}-14 \exp (-490 / \mathrm{T})$ & JPL02 \\
\hline $\mathrm{O} 3+\mathrm{NO} 2=\mathrm{O} 2+\mathrm{NO} 3$ & $1.20 \mathrm{E}-13 \mathrm{exp}(-2450 / \mathrm{T})$ & JPL97 \\
\hline $\mathrm{O} 3+\mathrm{MO} 2=$ & $2.90 \mathrm{E}-16 \exp (-1000 / \mathrm{T})$ & JPL02 \\
\hline $\mathrm{CO}+\mathrm{OH}=\mathrm{HO} 2+\mathrm{CO} 2$ & $\begin{array}{l}\mathrm{K} 0=1.50 \mathrm{E}-13 \\
\mathrm{~K}=\mathrm{K0}(1+0.6 \mathrm{Patm})\end{array}$ & JPL97 \\
\hline $\mathrm{CH} 2 \mathrm{O}+\mathrm{OH}=$ & $9.00 \mathrm{~A} 212$ & JPL 02 \\
\hline $\mathrm{CO}+\mathrm{HO} 2+\mathrm{H} 2 \mathrm{O}$ & & \\
\hline
\end{tabular}

Table 2A: Global model CO concentrations, Tg CO year ${ }^{-1}$.

\begin{tabular}{|c|c|c|}
\hline Year & $\begin{array}{c}\text { Global Anthropogenic } \\
\text { Emissions }\end{array}$ & Global Biomass Burning \\
\hline $\mathbf{2 0 0 1}$ & 469.8764 & 381.2404 \\
\hline $\mathbf{2 0 0 2}$ & 481.0323 & 435.5395 \\
\hline $\mathbf{2 0 0 3}$ & 493.982 & 415.3158 \\
\hline $\mathbf{2 0 0 4}$ & 496.483 & 423.2468 \\
\hline $\mathbf{2 0 0 5}$ & 496.951 & 421.7772 \\
\hline $\mathbf{2 0 0 6}$ & 498.416 & 410.1676 \\
\hline $\mathbf{2 0 0 7}$ & 493.611 & 426.953 \\
\hline $\mathbf{2 0 0 8}$ & 495.075 & 329.027 \\
\hline $\mathbf{2 0 0 9}$ & 493.618 & 328.0904 \\
\hline
\end{tabular}



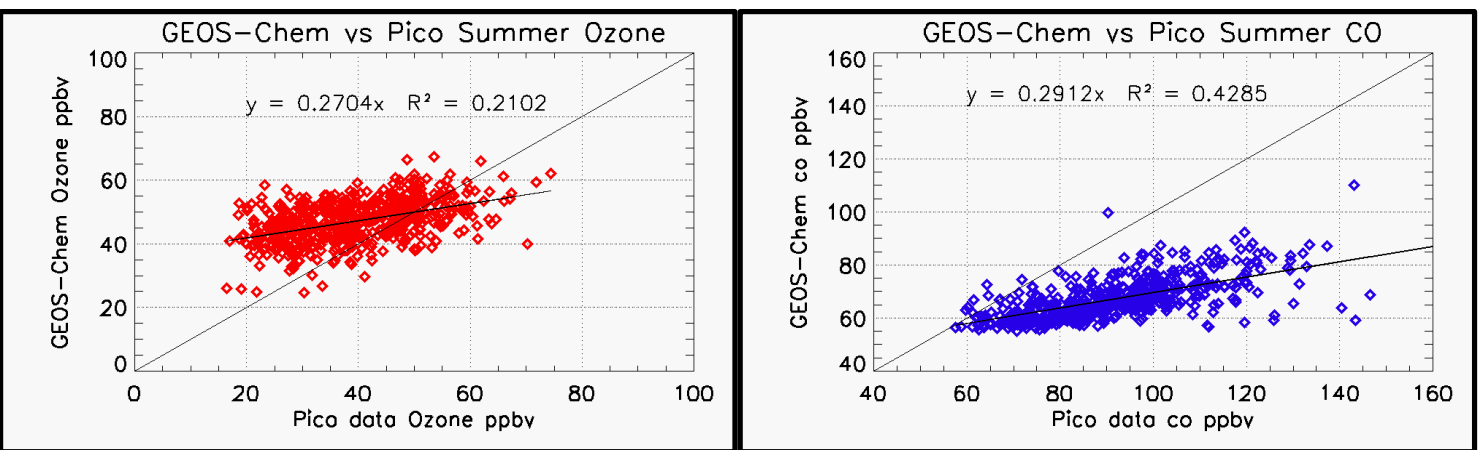

Figure A1: $\mathrm{O}_{3}(\mathrm{n}=568)$ and $\mathrm{CO}(\mathrm{n}=528)$ plots for GEOS-Chem and Pico data covering only the summer record.
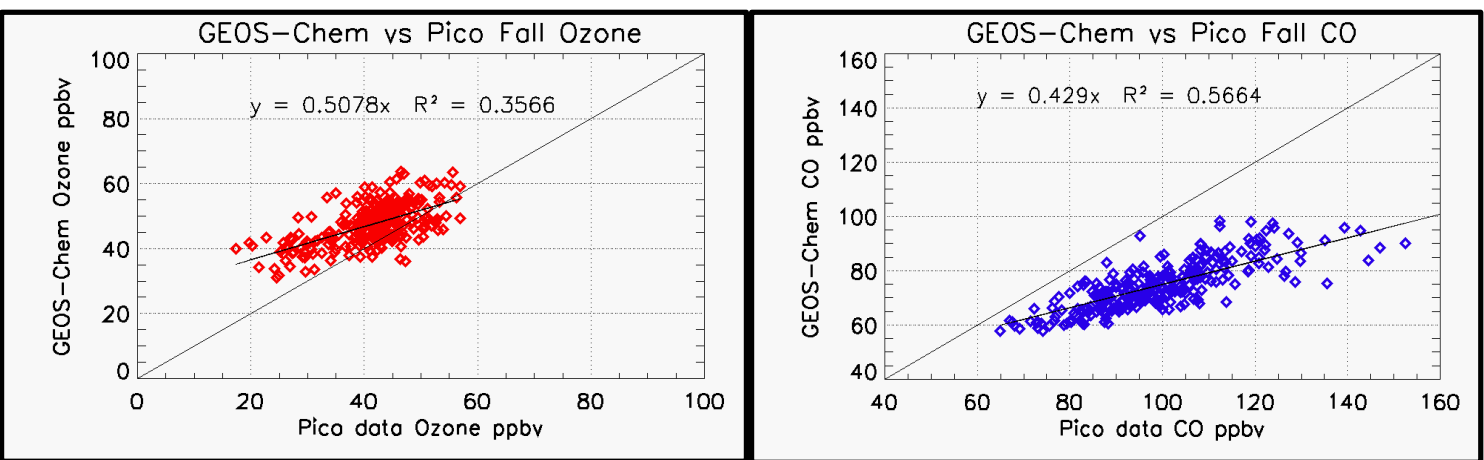

Figure A2: $\mathrm{O}_{3}(\mathrm{n}=272)$ and $\mathrm{CO}(\mathrm{n}=301)$ plots for GEOS-Chem and Pico data covering only the fall record.
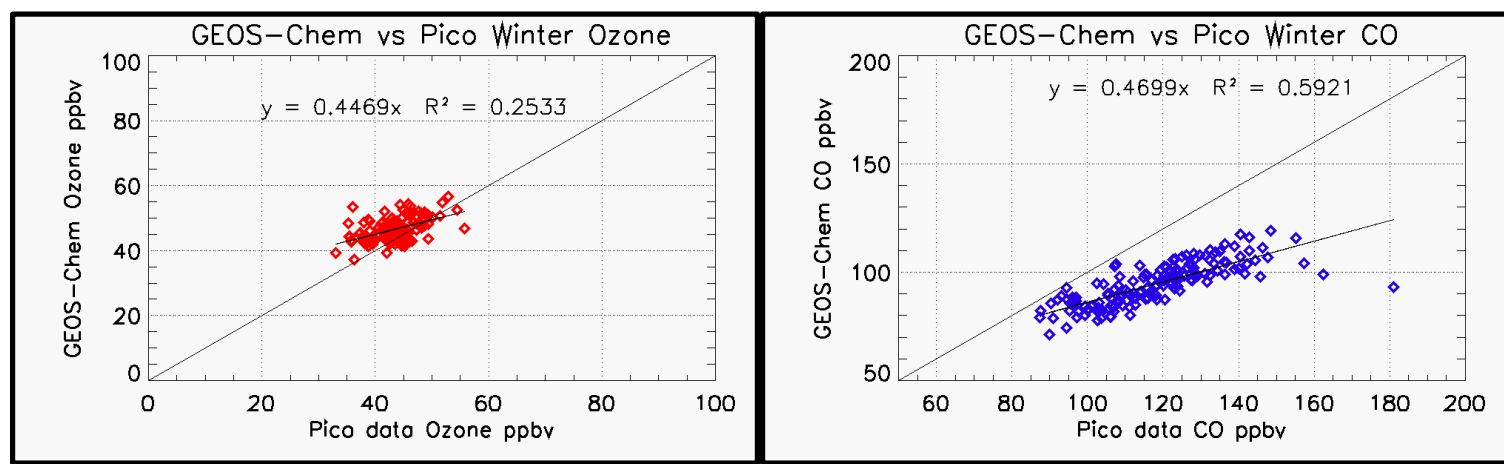

Figure A3: $\mathrm{O}_{3}(\mathrm{n}=116)$ and $\mathrm{CO}(\mathrm{n}=172)$ plots for GEOS-Chem and Pico data covering only the winter record. 

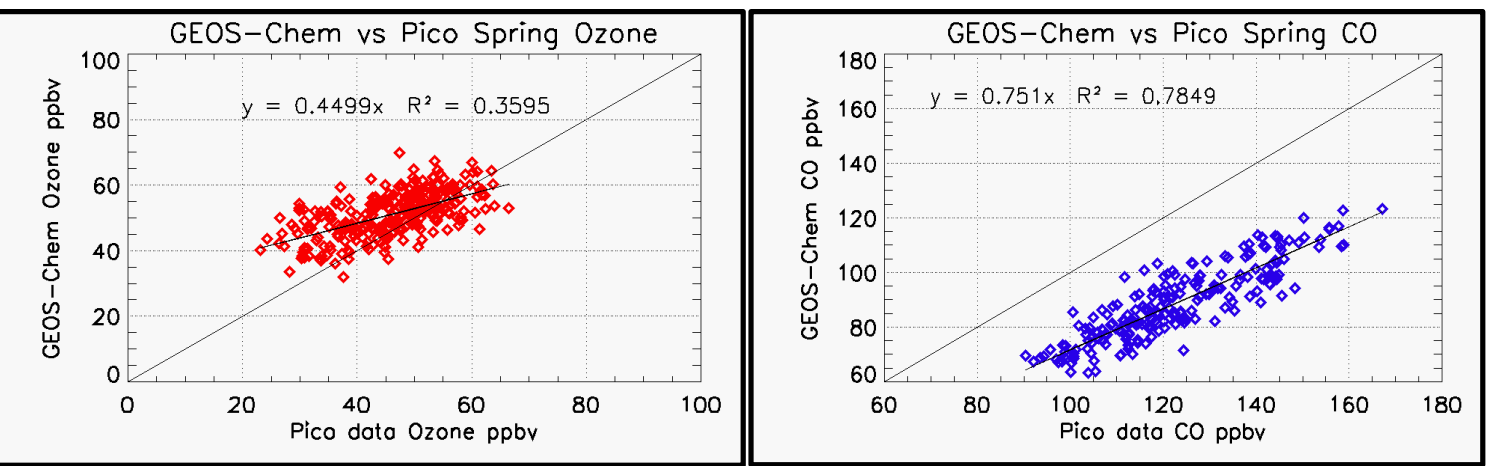

Figure A4: $\mathrm{O}_{3}(\mathrm{n}=292)$ and $\mathrm{CO}(\mathrm{n}=245)$ plots for GEOS-Chem and Pico data covering only the spring record.

Table A3: U.S. CO emissions listed by source category in thousand short tons for 2000 to 2008. Data available at: http://www.epa.gov/ttnchie1/trends/.

\begin{tabular}{|l|l|l|l|l|l|l|l|l|l|}
\hline $\begin{array}{l}\text { Source } \\
\text { Category }\end{array}$ & $\mathbf{2 0 0 0}$ & $\mathbf{2 0 0 1}$ & $\mathbf{2 0 0 2}$ & $\mathbf{2 0 0 3}$ & $\mathbf{2 0 0 4}$ & $\mathbf{2 0 0 5}$ & $\mathbf{2 0 0 6}$ & $\mathbf{2 0 0 7}$ & $\mathbf{2 0 0 8}$ \\
\hline $\begin{array}{l}\text { FUEL COMB. } \\
\text { ELEC. UTIL. }\end{array}$ & 484 & 485 & 657 & 652 & 647 & 643 & 661 & 680 & 699 \\
\hline $\begin{array}{l}\text { FUEL COMB. } \\
\text { INDUSTRIAL }\end{array}$ & 1219 & 1253 & 1267 & 1229 & 1190 & 1152 & 1173 & 1195 & 1216 \\
\hline $\begin{array}{l}\text { FUEL COMB. } \\
\text { OTHER }\end{array}$ & 3081 & 3088 & 3550 & 3477 & 3404 & 3331 & 3343 & 3356 & 3369 \\
\hline $\begin{array}{l}\text { CHEMICAL \& } \\
\text { ALLLED } \\
\text { PRODUCT MFG }\end{array}$ & 361 & 372 & 284 & 259 & 233 & 208 & 227 & 246 & 265 \\
\hline $\begin{array}{l}\text { METALS } \\
\text { PROCESSING }\end{array}$ & 1295 & 1380 & 987 & 934 & 882 & 829 & 869 & 908 & 947 \\
\hline $\begin{array}{l}\text { PEROLEUM \& } \\
\text { RELATED } \\
\text { INDUSTRIES }\end{array}$ & 161 & 162 & 357 & 355 & 353 & 351 & 352 & 353 & 355 \\
\hline $\begin{array}{l}\text { OTHER } \\
\text { ITDUSTRIAL } \\
\text { PROCESSES }\end{array}$ & 592 & 615 & 490 & 504 & 519 & 534 & 522 & 511 & 500 \\
\hline $\begin{array}{l}\text { SOLENT } \\
\text { UTILIZATION }\end{array}$ & 51 & 50 & 2 & 2 & 2 & 2 & 2 & 2 & 2 \\
\hline $\begin{array}{l}\text { STRAAGE \& } \\
\text { TRASSPORT }\end{array}$ & 169 & 178 & 118 & 114 & 111 & 107 & 110 & 113 & 115 \\
\hline $\begin{array}{l}\text { WASTE } \\
\text { DISPOSAL \& } \\
\text { RECYCING }\end{array}$ & 1849 & 1851 & 1594 & 1580 & 1567 & 1554 & 1564 & 1574 & 1584 \\
\hline $\begin{array}{l}\text { HIGHWAY } \\
\text { VEHICLES }\end{array}$ & 68061 & 63476 & 60596 & 56579 & 52562 & 48544 & 45318 & 42092 & 38866 \\
\hline OFF-HIGHWAY & 24178 & 24677 & 22662 & 21999 & 21336 & 20672 & 19793 & 18915 & 18036 \\
\hline MISCELLANEOUS & 12964 & 8676 & 18493 & 17364 & 16235 & 15106 & 13981 & 12856 & 11731 \\
\hline Total & $\mathbf{1 1 4 4 6 5}$ & $\mathbf{1 0 6 2 6 3}$ & $\mathbf{1 1 1 0 5 7}$ & $\mathbf{1 0 5 0 7 8}$ & $\mathbf{9 9 0 4 1}$ & $\mathbf{9 3 0 3 4}$ & $\mathbf{8 7 9 1 5}$ & $\mathbf{8 2 8 0 1}$ & $\mathbf{7 7 6 8 5}$ \\
\hline
\end{tabular}

\section{Guide to model directory and data storage}

The following is a brief description of the model runs and location of data, figures, and programs used in this report. For more detail please see the READ_ME directory located at 
/local/ctm_homes/mfweise/v8-3-1/READ_ME/. The main model directory path is /local/ctm_homes/mfweise/v8-3-1. All model bpch files are in the bpch directory. The model was initially run with GEOS-5 from 2004 through 2005; the path to these files is /bpch/GEOS5/. GEOS-4 was then run for 2000 through 2006; the path to these file is /bpch/GEOS4/. These runs were both started using the Harvard restart file '/restarts/geos.4x5.2008010100'. These files should not be used for data analysis. Various runs were created for analyzing which model to use. These include $/ \mathrm{bpch} / 2 \times 2.5 /, / \mathrm{bpch} / \mathrm{biomass} /, / \mathrm{bpch} / \mathrm{seasonalbio/.} \mathrm{The} \mathrm{bpch} \mathrm{files} \mathrm{containing}$ data used for data analysis are in /bpch/gfedmonthly/ and /bpch/ffemissions/. The corresponding 'input.geos' files are named according to the bpch files and are stored in /v8-3-1/inputlogs/.

Output $\log$ files are also named according to bpch files and are stored in /v8-3-1/logs/ with corresponding directories for each type of run (i.e. 'gfedmonthly', 'ffemissions').

Timeseries output for Pico station is in the /v8-3-1/timeseries/ directory. The naming convention follows those of the bpch files. Thus the final analysis was performed with /timeseries/gfedmonthly/ and /timeseries/ffemissions/. Directories labeled /timeseries/current_works/, /timeseries/current_works2/, /timeseries/current_works3/, and /timeseries/fire_events/ were used to temporarily store selected amounts of timeseries data for plotting.

All idlsav files used for plotting, including the idlsav file for Pico (all_pico_data.idlsav) are in /v8-3-1/idlsav. GEOS-Chem idlsav files were created for each species and were used to generate figures. If it was for trend analysis, the idlsav file has the word trend, if it was for the box and whiskers plot it is named 'box', and if it was for timeseries plotting the name contains 'ts'. 
All excel files used for data analysis and averaging are in /v8-3-1/excelfiles/. There are 2 each for $\mathrm{CO}$ and ozone as well as 1 for emissions and EPA data. The /v8-3-1/textfiles/ directory contains .csv files used to convert bpch timeseries data to idlsav files.

The /v8-3-1/IDL/ directory contains all IDL programs used. All timeseries plots have 'plot...ts.pro' in the name. One_box.pro, desc.pro, and test_box_plot_mark_2.pro were used to generate the box and whiskers plot. Makecsvfile.pro converts .bpch files to .csv files for use in excel or conversion to idlsav file format. To calculate GEOS-Chem emission emissionssum.pro was used.

All figures used in this paper are located in /v8-3-1/finalfigs/. Additional figures are located in /v8-3-1/output/ directory. 